Article

\title{
The Influence of the Middle East Respiratory Syndrome Outbreak on Online and Offline Markets for Retail Sales
}

\author{
Eunae Jung and Hyungun Sung * \\ Department of Urban Engineering, Chungbuk National University, 52 Naesudong-ro, Seowon-gu, Cheongju, \\ Chungbuk 361-763, Korea; eunae2111@naver.com \\ * Correspondence: hgsung@chungbuk.ac.kr; Tel.: +82-10-7187-6181
}

Academic Editor: Andrea Appolloni

Received: 28 December 2016; Accepted: 2 March 2017; Published: 9 March 2017

\begin{abstract}
This study investigates whether the Middle East Respiratory Syndrome (MERS) outbreak in Korea affected online and offline retail sales and determines the presence of a substitution or delay effect between the two. We analyze the monthly retail sales of electronic goods, semi-luxury goods, and groceries using an autoregressive integrated moving average (ARIMA) model with intervention. The findings are as follows. First, offline sales of electronic goods declined by $7.9 \%$, while online sales increased by $7.03 \%$, indicating that these markets can act as substitutes. Second, the offline sales of semi-luxury goods decreased for two months, while online sales remained the same, indicating that there can be a delay effect in the offline market. Finally, despite the slight increase in online sales and the moderate decrease in offline sales, the MERS outbreak did not have a statistically significant effect on grocery sales. Our research findings imply that stakeholders such as the government and retail provided useful information on how to deal with the unexpected outbreak.
\end{abstract}

Keywords: Middle East Respiratory Syndrome (MERS); online market; offline market; substitution effect; delay effect; retail sales

\section{Introduction}

The internet as a channel for electronic marketing has characteristics that are distinct from traditional physical markets [1]. Along with offline stores, the growth of online shopping offers various opportunities to consumers. Nowadays, consumers easily alternate between offline and online shops depending on the characteristics of the products that satisfy their demand [2-4]. In this environment, the outbreak of the Middle East Respiratory Syndrome (MERS) that occurred in May 2015 in South Korea hit the domestic economy hard [5], bringing considerable changes. When infectious diseases such as MERS, Severe Acute Respiratory Syndrome (SARS), and H1N1 (subtype of influenza A virus) spread, people worry about possible infections that can affect their outdoor activities [6,7], and thus consumer behavior [8,9]. In fact, as concerns were mounting over MERS among economic players, there were visible signs of economic slowdown across the nation, including a reduction in demand for tourism, entertainment, leisure, and dining and a shrinking private education industry caused by a temporary shutdown of schools [10].

The shock from the MERS outbreak prompted many researchers to examine its social, economic, and medical implications. However, economic studies on infectious diseases mostly focused on the hotel and tourism industry [6,11,12] or macroeconomic indices such as GDP [13], gross revenue [14], and the total number of people traveling in and out of the country [15].

As the retail market now offers a number of shopping channels for consumers, an external shock from an infectious disease such as SARS, H1N1, and MERS no longer translates into an automatic 
change in aggregate sales. The internet enables people to have a defense mechanism and avoid the fear of infection with its alternate market. Consumers can go out less and temporarily or permanently engage in reasonable purchasing according to the product characteristics. For example, when airborne viruses like MERS spread, consumers are more likely to shop online for daily essentials, rather than go to an offline store. In other words, the substitution effect would come into play between online and offline sales. On the other hand, consumers would try to avoid purchasing durable goods. Thus, there may also be a delay effect. To verify this, the present study investigates whether the outbreak of the MERS virus affected online and offline sales in a retail market with various shopping channels available [16], and whether the markets experienced the substitution or delay effect. We also examine whether substitution or delay effect prevails depending on product characteristics. The remainder of this paper is structured as follows. In the next section, we introduce the relevant literature and theories, develop a research framework, and propose our hypotheses. In the subsequent section, we categorize retail products into electronic goods, semi-luxury goods, and groceries based on several criteria, and then identify the differences among the three groups and describe the methodology used. In the fourth section, we analyze data from the records of monthly offline and online transactions with respect to the product type and findings. In the fifth section, we provide a brief summary and discussion of the findings, including the implications of adopting confrontation strategies for the stakeholders.

\section{Literature Review and Research Framework}

\subsection{Literature Review}

The spread of airborne infectious diseases such as SARS, H1N1, and MERS not only reduces people's outdoor activities [6,7,17-19], but also affects a nation's economy, including retail sales. Globalization, which is characterized by frequent international movement of people and goods, has made the spread of such diseases to other countries unpredictable [20,21]. Baek [22] defined today's globalized world as a risky society as its impacts are delocalized, incalculable, and non-compensable.

In this regard, many studies have explored the impacts of the proliferation of airborne infectious diseases, even though it is a relatively recent phenomenon in the 21st century. These studies have mainly focused on either a certain industry sector that is more sensitive to such outbreaks, or overall macroeconomic decline. For instance, the studies on the impacts of the SARS outbreak, which started in China, include studies on individual-level consumption [23], consumer behavior of domestic and foreign tourists in China [24-26], and the hotel industry [11]. Liu et al. [26] demonstrated that the outbreak of SARS ( $-64.31 \%$ ) influenced the loss of inbound tourists more than any other crisis event including the 1997 Asian financial crisis (-2.54\%), September 11 attacks $(-24.59 \%)$, the 2001 earthquake $(-17.07 \%)$ in Taiwan. Chi and Baek [27] suggested that the SARS outbreak had long-term impacts on air flight demand.

On the other hand, the economic impact studies on the SARS outbreak have focused on the impacts on macroeconomic indicators such as gross domestic product (GDP). Lee and McKibbin [28] claimed that it had resulted in a US $\$ 40$ billion loss to the world, especially for China and Hong Kong. In addition, Siu and Wong [29] reported that its impacts were negative, albeit short term, and on economic demand rather than supply. During the outbreak of H1N1 influenza, also known as "swine flu", the world economy experienced a $0.34 \%$ loss [30]. Jonung and Roeger [31] demonstrated that the pandemic of the Spanish flu outbreak of 1918 led to a loss of 1.6\% of Europe's GDP in its first year.

The pandemic of airborne infectious diseases impacts outdoor activities that are connected to economic loss. For instance, there was about $50 \%$ decrease in daily public transit ridership in the peak period of the SARS outbreak in Taipei city [32]. In addition, its outbreak made people visit hospitals even less than the 9/11 terrorist attack risk [32]. D'Arpizio [33] reported that retail sales for global luxury goods in the world decreased during its outbreak.

Several studies have been conducted on the economic impact of the MERS outbreak [12,34]. Ryu examined the effects of the MERS outbreak on a nation's tourism industry and economy using 
statistical data and made predictions about tourism demand and the domestic economy [34]. Moon and Han investigated how the decrease in the number of overseas visitors during the MERS epidemic influenced Seoul's distribution industry through an interregional input-output model [12].

A few studies have explored the impacts of the MERS outbreak on outdoor activities in South Korea. Kim et al. [18] reports that on 10 June 2015, which was one of the peak days of the outbreak, transit ridership fell by $11.8 \%$ in the Seoul metropolitan region and $13.88 \%$ in the areas with crowded facilities like inter-regional transit terminals, sports complex, big gathering places, and big hospitals. Sung and Kwak [19] also demonstrated that the MERS outbreak has led to a decrease in transit ridership in station areas with a relatively higher density of rail station areas. Their results are similar to Hanna and Huang [35], who identified that the risk of the SARS infection was greater in Asian countries with high population density. Further, Sung [17] reported that the impacts of the MERS outbreak can be heterogeneous in terms of start time, magnitude, and duration with respect to avoiding taking public transit. He reported that the decrease in transit ridership at the peak time was for a very short period and was even shorter during the outbreak and proliferation of MERS, while it was more long term and the decrease in transit ridership was greater on off-peak afternoons. In another study, Kim [6] identified the effects of infectious disease on less visits to public libraries.

By studying the impact of an external shock on domestic consumption using time series plots of transactions made via debit and credit cards, Jung et al. examined how the MERS outbreak affected consumer expenditures from a microeconomic perspective [9]. They found that the outbreak and proliferation of MERS considerably disrupted total consumer expenditure, which had a heterogeneous pattern in five retail categories that include recreation/culture, dining, department store, e-commerce, and grocery stores. They demonstrated that offline expenditures on recreation/culture, dining, and department store significantly decreased by $6.87 \%, 8.24 \%$, and $18.01 \%$, respectively, during the outbreak, while the retail expenditures through e-commerce increased during the outbreak, but not significantly for grocery stores.

The impacts of airborne infectious diseases can be homogeneous, based on the research results of studies such as Chi and Baek [27] and Sung [17]. Most of the studies mentioned above have dealt with its fixed and constant impacts, irrespective of its issue, during a defined number of days, months, and years. Some studies $[9,17]$ indicated that its impacts were heterogeneous among different categories of retail goods. In addition, Jung et al. [9] claimed that the online market can substitute the offline market in retail sales. Therefore, based on the review of literature, we not only explore how the impact of the MERS outbreak on retail sales persisted, but also how the relationship between online and offline markets is differentiated in sales of different retail goods.

\subsection{Middle East Respiratory Syndrom (MERS) Outbreak and Its Prevention Efforts}

MERS is a respiratory infectious disease caused by the coronavirus that spreads through human bodies via close contact with an infected person. With symptoms that include fever, cough, and shortness of breath, it is known to be more fatal than SARS [36]. Moreover, it has also been observed that the elderly are more vulnerable than any other age group [37,38].

Since the MERS outbreak on 20 May 2015 in Korea, citizens have experienced the fear of infection and even death. Figure 1 presents the daily trend of infection, quarantine, and death related to the disease after the outbreak. The first death was reported on 1 June two weeks after the first infected person in Korea was diagnosed. The fear of infection and death spread further among the Korean people after a teenager was confirmed to be infected for the first time on 10 June. Around 20 citizens were infected every day during mid-June and one of Korea's biggest hospitals was partially closed on 14 June because of the mass infection. Eventually, many more people were infected and quarantined. The proliferation of the disease was reported to have gradually decreased after $17 \mathrm{July}$, recording a maximum of 6729 people quarantined at a time. 


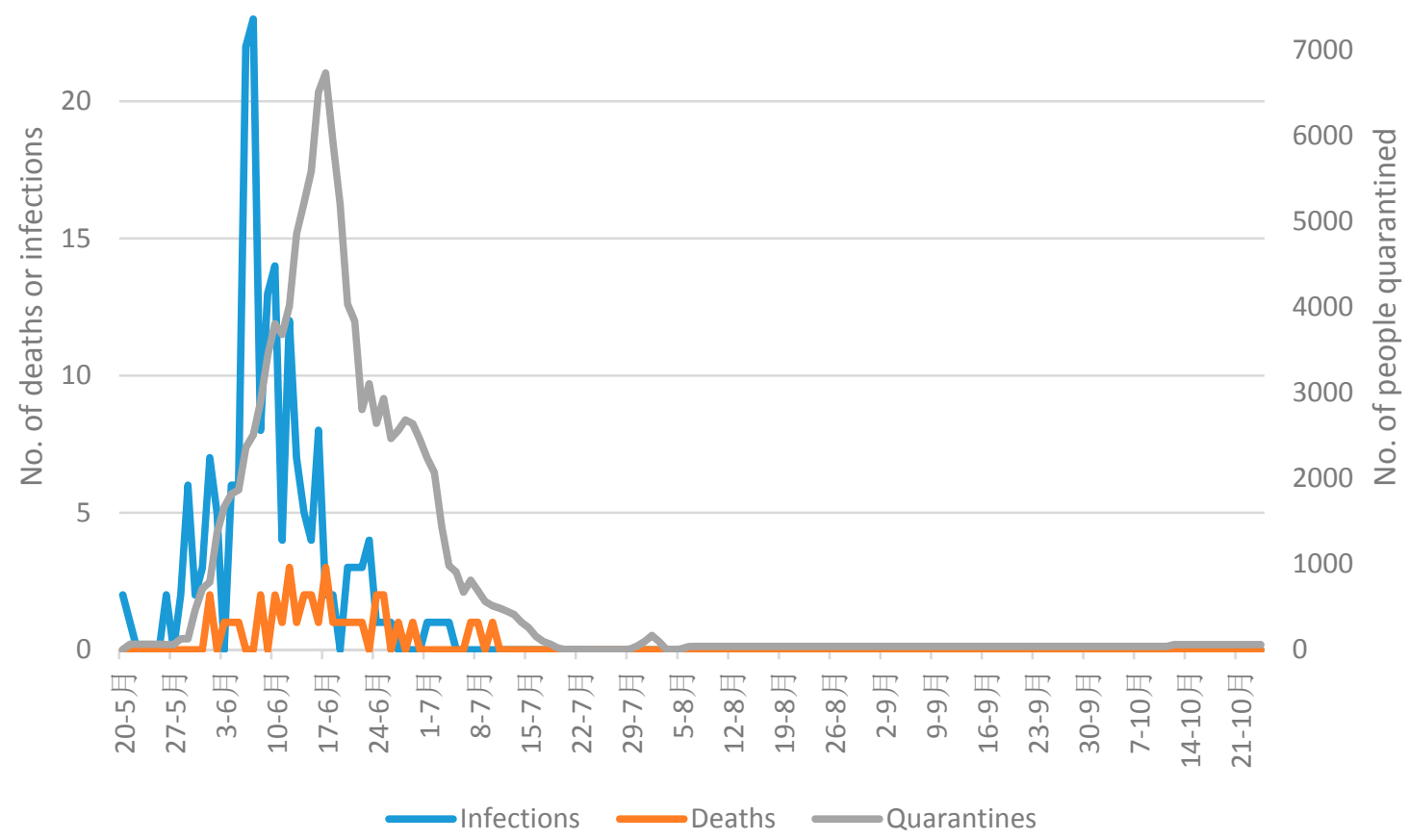

Figure 1. Daily status on deaths, infected patients, and quarantined people during the MERS outbreak.

During the outbreak and proliferation, the Korean central government recommended ordinary citizens to continue participating in socio-economic activities; the government believed that there was no epidemic because it was mainly limited to the elderly and because the hospitals with infected patients were not open to the public The government disclosed the information to the public on 7 June 2015, after 45 more patients were confirmed to be infected during the observation in the previous two days. At that time, a teenager was reported to have been infected for the first time. Further, some infected patients took public transit and visited multiple hospitals before receiving a definite diagnosis. This may have instigated the fear of getting infected through daily outdoor activities among the citizens. In addition, individual economic agents such as departments, medical institutions, and transit authorities tried to prevent visitors from getting infected by cleaning the facilities and providing detergents. This fear may have impelled them to avoid daily outdoor activities during the MERS outbreak and even after it was contained. The white paper published by the government of the city of Seoul reported a loss of 38\% foreign tourists and 12\% transit riders during the first two weeks of June 2015 [39].

\subsection{Research Framework and Hypothesis}

During the MERS outbreak, many Korean citizens may have refrained from going outdoors, thereby reducing their offline consumption expenditure of daily retail goods. Higgins's regulatory focus theory and Freud's defense mechanism theory may provide an explanation for this behavioral change of the Korean population towards offline shopping [9,40,41]. People have a strong desire for safety, which has a significant influence on consumer behavior including their perceptions, motivations, and actions [40,42]. In particular, prevention focus theory According to the regulatory focus theory, people use two kinds of regulatory focus to reach their goals: promotion focus and prevention focus. People with prevention focus try to avoid situations not in line with their goals and take a vigilant approach to prevent a failure to accomplish their goals helps explain why people changed their behavior in response to the MERS outbreak: in an attempt to counter the unexpected risk of getting infected by the virus, people took preventative measures such as avoiding crowded public places and facilities $[18,43]$ and reducing the use of public transportation $[17,19]$. This changed the purchasing 
behavior for retail goods that comprise daily necessities, while also possibly delaying purchases or moving people to online markets.

With regard to delaying purchases or moving to online markets, Freud's concept of displacement is relevant as well [41]. It is an unconscious defense mechanism whereby a person shifts his/her impulses from an unacceptable target to a more acceptable or less threatening one. It may occur when, under the threat of getting infected by an epidemic, people refrain from acquiring certain goods especially when substitutes are available from alternative markets [40,44,45]. Based on Jung et al. [9], it can be assumed that potential consumers moved from offline to online retail markets via the internet on mobile devices during the MERS outbreak. In a situation where people were unable to purchase goods from either market, they may have delayed their purchases. For the goods that could not be obtained online, people had no choice but to purchase them in person despite the fear of being infected through outdoor activities. In addition, the purchasing behavior of consumers can be differentiated, depending on what they needed or wanted to buy during the MERS outbreak. For instance, consumers may have relied more on online shopping channels to buy daily necessities like groceries until the MERS epidemic ended. In other words, there is a substitution effect as people indirectly purchased daily essentials through online rather than offline markets. On the other hand, when a purchase is postponed because of an immediate risk of getting infected, a delay effect prevails.

Korea is one of the world's ICT powerhouses, with a variety of distribution channels, such as online and mobile shops, available to Korean consumers over and above conventional offline shops [46,47]. Online shopping has become popular among almost all Koreans. Therefore, when outdoor activities are deemed dangerous due to an epidemic such as the MERS outbreak, many Koreans may have shopped through the online channels as it guarantees a higher level of safety than the offline ones [9].

In line with the assumptions of these theories on consumer behavior, Figure 2 illustrates the process of change in purchasing behavior with respect to online and offline markets. This process has four steps: (1) the outbreak and proliferation of MERS; (2) refraining from outdoor activities; (3) change of consumption patterns; (4) change of shopping patterns depending on product characteristic, groceries, semi-luxury goods like clothing and electronics. Dhār and Wertenbroch and Levin et al. suggest that people prefer shopping offline to buying products such as clothes because they want to see them in person before purchasing [47-51]. In contrast, people like to buy electronic goods such as CDs or computers online because these items are standardized. It is thus implied that people prefer quality to convenience for purchasing standardized goods such as electronic devices and tickets, which are homogeneous in nature [49,52]. Such behaviors occur more often during an unexpected event like the MERS outbreak. As people need daily necessities such as groceries, there was a substitution effect whereby people moved to safe distribution channels including online shops. For modern requirements of electronics and communication products for both daily life and work, consumers preferred online purchases. However, for goods such as clothing and shoes, the delay effect should occur as these items have the characteristics of both luxury and consumption goods and people do not feel an urgent need for them.

The following three hypotheses have been formed from the theoretical background discussed here and the findings of previous studies:

Hypothesis 1. As people desire to purchase retail goods, but do not want to get infected with MERS, online markets act as a substitute for offline markets.

Hypothesis 2. When consumers do not need to purchase retail goods urgently, there is a delay effect in offline markets and they do not move to online markets.

Hypothesis 3. Changes in online and offline markets differ depending on the characteristics of the goods. 


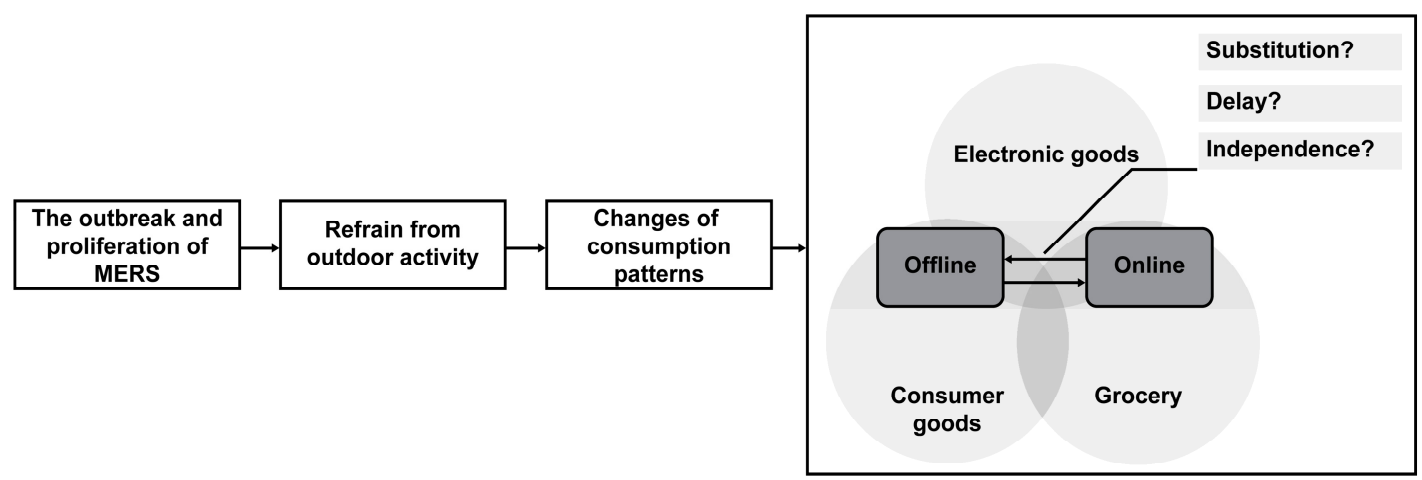

Figure 2. Framework of the relationship between online and offline shopping by product characteristics.

\section{Materials and Methods}

\subsection{Data and Classification}

The data includes the monthly offline sales and online turnover by product category obtained from the Korean Statistical Information Service (KOSIS), an agency under Statistics Korea. The records were collected for the period from January 2010 to April 2016. Time series analysis requires at least two seasonal periods to capture any variation. If our monthly data would have the characteristic of a fluctuating trend, it is better to have a longer period to capture the trend variation. That is, it is necessary to have as long a period as possible to identify the duration of the impact of the MERS outbreak. We reclassified retail goods on the basis of information asymmetry, product involvement, the degree of standardization, durability, price, outdoor activities involving the purchase, and utility to suit the purpose of this study. Many studies have reported the relationship between consumers' preference and product class in online shopping [53-56] The classification based on product attributes is a useful means to evaluate the influence on traditional marketing channels [53,56-58], and several studies have accepted that consumers' buying behaviors vary with respect to the type of product $[54,59]$.

Products can be classified into search and experience goods depending on the level of information asymmetry [55,57,60-62]. Nelson [60,61] defines search goods as those goods whose dominant product attributes can be known prior to purchase and experience goods as those goods whose attributes cannot be determined or determined with difficulty and high cost prior to purchase [42,48,49]. Hsieh et al. [63] describes search goods as those goods that are associated with a higher level of standardization [63]. Zeithaml et al. [64] cite clothing and furniture as having search attributes because they can be easily evaluated before purchase [64]. Wang et al. cites vacations, telecommunications, or restaurants as examples of experience goods because of their intangible nature and the inability to evaluate their quality until after having purchased them [1]. Based on Nelson [60,61], Darby and Karni [55] define credence goods as those goods whose level of quality of an attribute can never be determined by the average consumer [65-67]. Credence goods are mostly found in professional contexts, such as medical services and pension plans [68]. Wang et al. [1] proved that substitution effect would be more evident in the case of search goods, rather than experience goods.

Product involvement has been regarded as an important criterion in making purchase decisions [69]. It refers to the extent to which a product can fit consumers' interests or concerns $[67,70]$. Consumers are more likely to search information on high involvement products, such as electronics, across many situations [65]. However, consumers may have fewer experiences of low-enduring involvement products toward frequently purchased household goods such as detergents [1]. Product involvement is relevant to price because consumers' interest or concern generally increases with the price of goods.

The retail products used by Kim involve outdoor activities based on physical buying patterns [66]. For example, products like clothing, for which consumers place great value on the ability to 
physically inspect the items [48], are categorized as shopping products. In contrast, products such as books and toothpaste, for which consumers place little value on inspection, are categorized as convenience products [48]. Levin et al. grouped products into high-touch, low-touch, and mixed-touch categories [48]. Clothing is a high-touch product and an airline ticket is a low-touch product. Books, electronic entertainment products, and computer products are mixed products.

KOSIS, the Korean Statistical Information Service, categorized products into durables, semi-durables, and non-durables based on durability and price [71]. The current study categorized products into three groups for analysis based on previous studies: electronic goods, semi-luxury goods, and groceries in online and offline markets. That is, we used the criteria of information asymmetry, product involvement, standardization, durability, price, outdoor activities, and utility based on KOSIS and Kim [66,71] (Refer to Table 1). The analysis excludes products such as cars because short-term events have little impact on this category. Electronic goods include items such as home appliances, communication devices, and computers, which can be used for more than a year, have specific functions, and whose sales may be affected by an external shock. Semi-luxury goods are items that are useable for more than a year but are purchased by consumers as and when they wish, such as clothing, shoes, bags, and accessories. Finally, groceries include food, beverages, produce, seafood, and cosmetics. As we applied an autoregressive integrated moving average (ARIMA) with intervention model for time series analysis, we used inflation-adjusted constant prices, deflated by the consumer price index as of 2010, which was released by Statistics Korea.

Table 1. Product classification.

\begin{tabular}{|c|c|c|c|}
\hline Research & Classification Criteria & Product Categories & Examples \\
\hline $\begin{array}{l}\text { Darby and Karni [55] } \\
\text { Nelson [60,61] } \\
\text { Klein [57] } \\
\text { Brucks et al. [62] } \\
\text { Zeithaml and Bitner [64] } \\
\text { Asch [68] } \\
\text { Hsieh et al. [65] } \\
\text { Huang et al. [72] } \\
\text { Wang et al. [1] }\end{array}$ & $\begin{array}{l}\text { Different roles of } \\
\text { shopping orientation, } \\
\text { standardization }\end{array}$ & $\begin{array}{l}\text { Search Experience } \\
\text { Credence }\end{array}$ & $\begin{array}{l}\text { clothing and furniture vacations, } \\
\text { telecommunications, or restaurants } \\
\text { medical services and pension plans }\end{array}$ \\
\hline $\begin{array}{l}\text { Zaichkowsky [61] } \\
\text { Celsi and Olson [69] } \\
\text { Suh and Youjae [67] } \\
\text { Wang et al. [1] }\end{array}$ & $\begin{array}{l}\text { The degree of product } \\
\text { involvement, price }\end{array}$ & $\begin{array}{l}\text { High-involvement } \\
\text { products } \\
\text { Low-involvement } \\
\text { products }\end{array}$ & electronic products household goods \\
\hline KOSIS [71] & Durability, price & $\begin{array}{l}\text { Durability Durable goods } \\
\text { Non-durable goods }\end{array}$ & $\begin{array}{l}\text { home appliances, communication } \\
\text { devices and computers, furniture } \\
\text { Clothing, shoes and bags, } \\
\text { entertainment goods, hobbies or } \\
\text { sports Food and beverages, medicine, } \\
\text { cosmetics, books, and stationery }\end{array}$ \\
\hline $\begin{array}{l}\text { Kim [64] } \\
\text { Levin et al. [53] }\end{array}$ & Buying pattern & $\begin{array}{l}\text { Shopping goods } \\
\text { Convenience goods }\end{array}$ & $\begin{array}{l}\text { Clothing, home appliances Books, } \\
\text { CDs, toothpaste }\end{array}$ \\
\hline This study & $\begin{array}{l}\text { Product involvement, } \\
\text { standardization, } \\
\text { durability, price, outdoor } \\
\text { activities, utility }\end{array}$ & $\begin{array}{l}\text { Electronic goods } \\
\text { Semi-luxury goods } \\
\text { Groceries }\end{array}$ & $\begin{array}{l}\text { Home appliances and communication } \\
\text { devices, computers Clothing, shoes, } \\
\text { bags, accessories, etc. Food and } \\
\text { beverages, agriculture and marine } \\
\text { products, cosmetics }\end{array}$ \\
\hline
\end{tabular}

\subsection{Methodology and Research Process}

There are four potential alternative methodologies to identify the duration of the effects of the MERS outbreak on sales of different retail goods and determine how the relationship between online and offline markets are heterogeneous for different categories of retail goods. The first alternative is a simple direct comparison method for examining within-month sales difference before and after the MERS outbreak. It was employed by Kim et al. [18] to explore the decrease in transit ridership by Traffic 
Analysis Zone (TAZ) during the peak day of the MERS outbreak and proliferation, with respect to the same day of the previous year. However, unlike transit ridership, our monthly sales data has different trends and seasonal variations in retail sales of online and offline markets, as presented in Appendix A, which additively breaks retail sales down into trends, seasonality, and random error factors. That is, it is difficult to determine the net impact because of the variations. It can be biased because of the different trend and seasonal variations. For example, in 2015, retail sales in offline markets decreased in months like January and February before the MERS outbreak, May and June during the outbreak, and September and December after the outbreak, in comparison to the same months of the previous year, as presented in Appendix B. As another example, sales of offline semi-luxury goods decreased in January, February, March, June, July, August, September, and December in 2015. Thus, the direct comparison method is not appropriate for our study.

The second alternative is a linear regression model, which takes monthly retail sales as a dependent variable and the periods of the MERS outbreak and proliferation as well as each month as independent dummy variables. It was adopted by Jung et al. [9] to explore the impact of the MERS outbreak on consumer expenditures. However, unlike their study, our data had significant autocorrelation, thus rendering this method unsuitable for our study. The third alternative is comparing the difference between the actual monthly ridership values and the forecasted ones after applying the ARIMA model without the intervention for the period of the MERS outbreak. It was applied by Sung [17]. He identified the amount of decrease in transit ridership and its impact duration using daily transit ridership data. Despite being useful for our study, we did not employ this method because we could not confirm whether the differences and duration are statistically significant.

The last alternative is to employ an ARIMA model with intervention to analyze and determine the changes, variations, and interventions over time [73,74]. It is called the autoregressive integrated moving average with exogenous variables (ARIMAX) model. In this study, only one external dummy variable is considered for the MERS outbreak. This method has become a standard model for evaluating the impact of intervention from time-dependent data, irrespective of whether an external shock is planned or unexpected, [75-77]. That is, it is useful for identifying the net impact and its duration after controlling for trends and seasonal factors. This model has been employed to investigate external intervention effects such as flood control policy [74], institutional urban transition [76], stock price change [73], financial crisis [75], and government policy on importing Indian gold [77]. Therefore, we finally employ the ARIMA with intervention model to determine the heterogeneous net impacts and their duration on sales of retail goods in both offline and online markets.

The analysis proceeds with the following five steps: First, we draw the time plots of monthly sales for the period from January 2010 to April 2016. We then examine the characteristics of the time series of online and offline sales. From the time plots, we confirm how the MERS outbreak affected the monthly online and offline sales in different categories. We also make a preliminary prediction of when the MERS intervention began, its duration, and the magnitude of its impact. We used this as a basis for a pre-MERS prediction model and employed a Box-Jenkins ARIMA model. Second, we test it using an autocorrection function (ACF), partial autocorrelation function (PACF), and a portmanteau test. The ACF and PACF indicate the correlation between two points in a time series. We can find the presence of white noise in the error terms by examining the ACF and PACF of the residual. The portmanteau test is another tool to check for a residual's white noise; if a portmanteau (Q) test confirms a model's null hypothesis, the model is considered fit [58]. Third, we design an appropriate intervention model after accounting for the beginning of the episode and its duration. We estimate the model using a pulse function $\left(\boldsymbol{P}_{t}^{(T)}\right)$ or a step function $\left(S_{t}{ }^{(T)}\right)$, depending on when the intervention started and the duration for which it persisted. We also estimate the final model using the maximum likelihood estimation method.

Then, we diagnose the model fit with ACF, PACF, and a portmanteau test. In the final step, we interpret the model and produce the results. Figure 3 illustrates the entire process. 


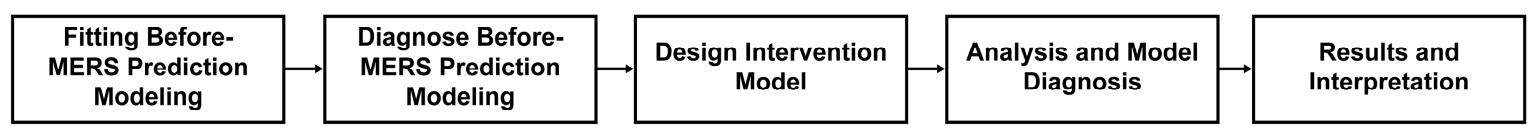

Figure 3. Research process.

\subsection{Models}

In this study, we use an autoregressive integrated moving average (ARIMA) model with intervention, which can help analysts determine whether an event affects a time series if they know the source and timing of the intervention. It indicates the duration and the way the effect, if any, persists. This model is appropriate for the current study because we know that the MERS outbreak, which started in May 2015, caused the intervention in the offline and online sales channels.

As expressed in Equation (1), when an intervention-free time series $Z_{t}$ follows the ARIMA $(\boldsymbol{p}, \boldsymbol{d}, \boldsymbol{q}) \times(\boldsymbol{P}, \boldsymbol{D}, \boldsymbol{Q})_{S}$ (pre-intervention) model with a seasonal period of $\mathrm{S}$, an external shock, $\boldsymbol{m}_{t}$, has an additive impact. $Z_{t}$ is the time series before the outbreak of MERS, and $m_{t}$ is the function indicating the impact of the outbreak.

$$
\begin{gathered}
Y_{t}=m_{t}+Z_{t} \\
(\mathbf{1}-\boldsymbol{B})^{d}(\mathbf{1}-\boldsymbol{B})^{D} \boldsymbol{\phi}_{p}(\boldsymbol{B}) \boldsymbol{\Phi}_{p}\left(\boldsymbol{B}^{s}\right) Z_{t}=\boldsymbol{\theta}_{0}+\boldsymbol{\theta}_{q}(\boldsymbol{B}) \Theta_{Q}\left(B^{s}\right) \boldsymbol{a}_{t}
\end{gathered}
$$

$Y_{t}$ includes the intervention, which implies that it is the full time series of the online and offline retail sales of each product category. $\boldsymbol{\phi}_{p}(\boldsymbol{B})$ is a non-seasonal AR polynomial, $\boldsymbol{\Phi}_{p}\left(\boldsymbol{B}^{s}\right)$ is a seasonal AR polynomial, $\boldsymbol{\theta}_{q}(\boldsymbol{B})$ is a non-seasonal MA polynomial, $\boldsymbol{\Theta}_{Q}\left(\boldsymbol{B}^{s}\right)$ is a seasonal MA polynomial, and $\boldsymbol{a}_{t}$ is white noise $\mathbf{W N}\left(\mathbf{0}, \sigma^{2}\right)$.

In Equation (1), we can calculate $m_{t}$, the effect of the MERS intervention, either with the pulse function $\boldsymbol{P}_{t}{ }^{(T)}$ or the step function $S_{t}^{(T)} . P_{t}^{(T)}$ applies when a certain event happens at time $T$ and its effect is limited to only that moment, which we define in Equation (2) below.

$$
P_{t}^{(T)}=\left\{\begin{array}{l}
0, t \neq T \\
1, t=T
\end{array}\right.
$$

$S_{t}{ }^{(T)}$ applies when the effect continues after $T$, as in Equation (3) below.

$$
S_{t}^{(T)}=\left\{\begin{array}{l}
0, t<T \\
1, t \geq T
\end{array}\right.
$$

For example, with regard to this study, if the effect of the MERS outbreak appeared at one specific point, such as May or June, $\boldsymbol{P}_{t}^{(T)}$ applies; however, if the effect remains for several months, then $\boldsymbol{S}_{t}{ }^{(T)}$ applies. $\boldsymbol{T}$ is May 2015, the time of the MERS outbreak.

Equation (4) provides the general calculation of how an intervention appears.

$$
m_{t}=\frac{\omega(B)}{\delta(B)} B^{b} I_{t}, I_{t}=P_{t}^{(T)} \text { or } I_{t}=S_{t}^{(T)}
$$

Here, $\omega(B)=\omega_{0}-\omega_{1} B-\cdots \omega_{s} B^{s}$ and $(B)=\delta_{0}-\delta_{1} B-\delta_{r} B^{r}$. refers to the time lag of the MERS effect. For instance, if a decrease or increase in online and offline sales caused by MERS appears in June rather than in May when the outbreak began, then $\boldsymbol{b}=1 . \omega(B)$ is the expected effect at the early stage of an intervention and $\delta(B)$ is the persistent effect of the intervention. Thus, $\omega(B)$ indicates the degree of impact of the MERS outbreak on sales, and $\delta(B)$ the duration for which the impact persisted. 


\section{Results}

Before the empirical analysis, we examined the original time series for six separate sales categories, all of which indicated heteroscedasticity, trends, and seasonality. We performed log transformations, first difference, and seasonal difference checks on the six original time series to eliminate non-stationarity. We also used data of the period from January 2010 to April 2015 to create the pre-intervention model and confirmed the appropriateness of our model through the ACF, PACF, and portmanteau test. Further, using the ACF, PACF, and portmanteau test, we confirmed that the final model including the intervention is appropriate.

\subsection{Electronic Goods}

Figure 4 illustrates the time series plot of electronic goods. Offline sales went down in June, the month following the MERS outbreak. The effect of MERS seemed insignificant, but sales in June 2015 dropped considerably as compared to the figures in the same month of the previous year. As the intervention had its effect only in June 2015, we applied $P_{t}$.

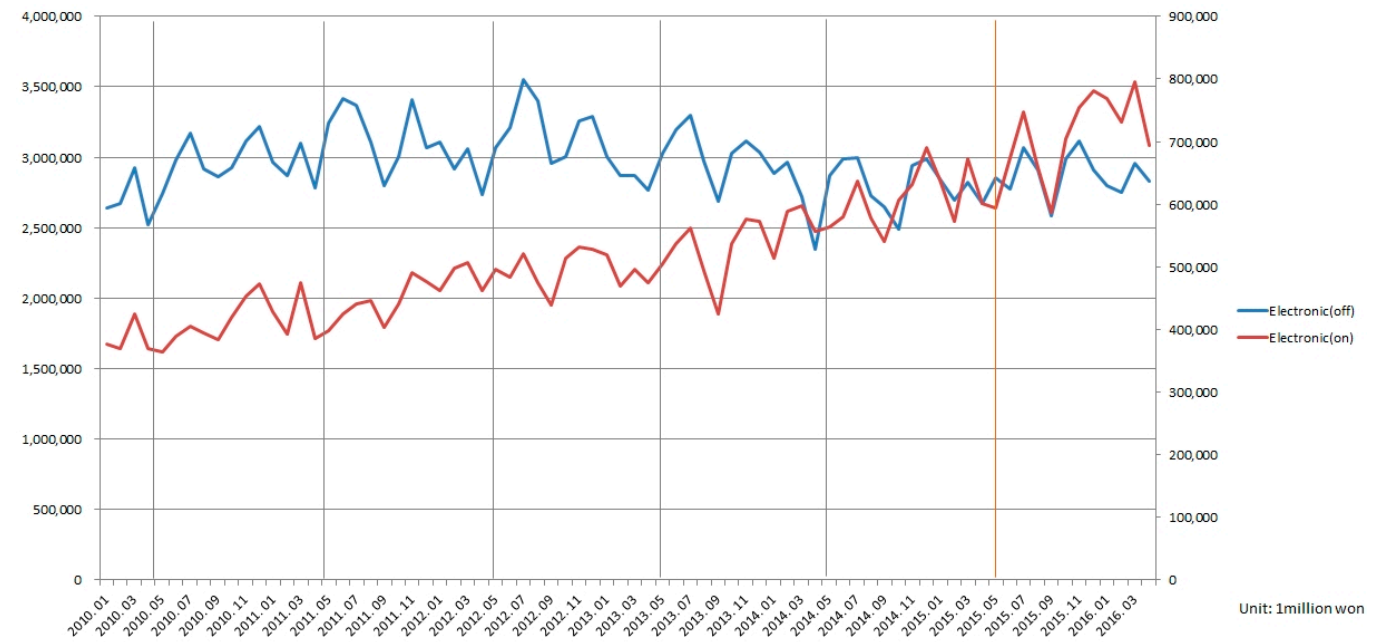

Figure 4. Time series plot for electronic goods.

Meanwhile, online sales grew in June 2015 and further went up in July. The year-on-year comparison indicated that sales increased every year from May except in 2012. As we confirmed that the effect of the MERS epidemic appeared in June and July, we employed $S_{t}$.

Table 2 presents the results from the final models for both offline and online sales. The results indicated that the offline sales of electronic goods in June declined by $7.97 \%=\{1-\exp (-0.083)\} \times 100$ due to the MERS outbreak. There was no significant change in online sales in June, but the intervention had a significant impact in July. Considering only the significant values, we found that the online sales of electronic goods increased by $7.03 \%=\{1-\exp (0.068)\} \times 100$ in July. The reduction in offline sales is consistent with the results reported by Ryu and Jung et al., who found that fewer outdoor activities due to the spread of airborne infections causes a reduction in outdoor consumption activities [9,35]. This result could be indirectly derived from Cheema and Papatla [78], who stated the relative importance of online information for utilitarian products (computer hardware and software) over hedonic products (books, music, and movies). These findings support Hypothesis 2, which relates to the change in offline and online sales due to the MERS outbreak. While electronic goods are not directly linked to consumers' basic needs for food, clothing, and shelter, they are vital tools for performing current economic activities. Thus, we predict that while people refrained from going outside amidst the fear of MERS [6,8], they acquired the necessary electronic goods from online markets. This result proved that the substitution effect exists between the online and offline markets for electronic goods. 
Table 2. Electronic goods results.

\begin{tabular}{cccccccc}
\hline & \multicolumn{2}{c}{ Offline } & \multicolumn{4}{c}{ Online } \\
\hline & Estimates & $\begin{array}{c}\text { Standard } \\
\text { Error }\end{array}$ & $p$-Value & & Estimates & $\begin{array}{c}\text { Standard } \\
\text { Error }\end{array}$ & $p$-Value \\
& & & & & -0.81 & 0.1 & 0.00 \\
$\boldsymbol{\theta}$ & -0.532 & 0.123 & 0.00 & $\boldsymbol{\theta}$ & -0.619 & 0.091 & 0.00 \\
$\boldsymbol{\Phi}$ & -0.26 & 0.149 & 0.08 & $\boldsymbol{\Phi}$ & 0.028 & 0.05 & 0.57 \\
$\boldsymbol{\Theta}$ & -0.999 & 0.319 & 0.00 & $\omega_{0}$ & 0.028 \\
$\omega_{\mathbf{0}}$ & -0.083 & 0.039 & 0.03 & $\omega_{\mathbf{1}}$ & 0.068 & 0.036 & 0.06 \\
& & & & $\boldsymbol{\delta}_{\mathbf{1}}$ & 0.998 & 0.081 & 0.00 \\
\hline AIC & & -234.76 & & AIC & & -181.28 & \\
\hline
\end{tabular}

Note: $\omega_{i}$ : expected effect at the early part, $\delta_{i}$ : persistent effect, $\phi, \Phi:$ AR polynomial, $\boldsymbol{\theta}, \boldsymbol{\Theta}:$ MA polynomial.

\subsection{Semi-Luxury Goods}

Figure 5 illustrates the time series plot for semi-luxury goods. Offline sales of semi-luxury goods are subject to seasonal effects. As compared to sales in the previous years, sales in June 2015 plummeted after the outbreak. The effects of the intervention persisted until July 2015. Sales in August can be located at the drop point, as in previous years. As the intervention began in May 2015, time delay was $b=1$ and the intervention was effective in June and July of 2015; therefore, we applied $S_{t}$. The general trend of online sales of semi-luxury goods seemed unchanged from the usual pattern. However, a closer examination indicates that online sales dropped less in June 2015 after the outbreak as compared to the drops in the same month of 2013 and 2014.

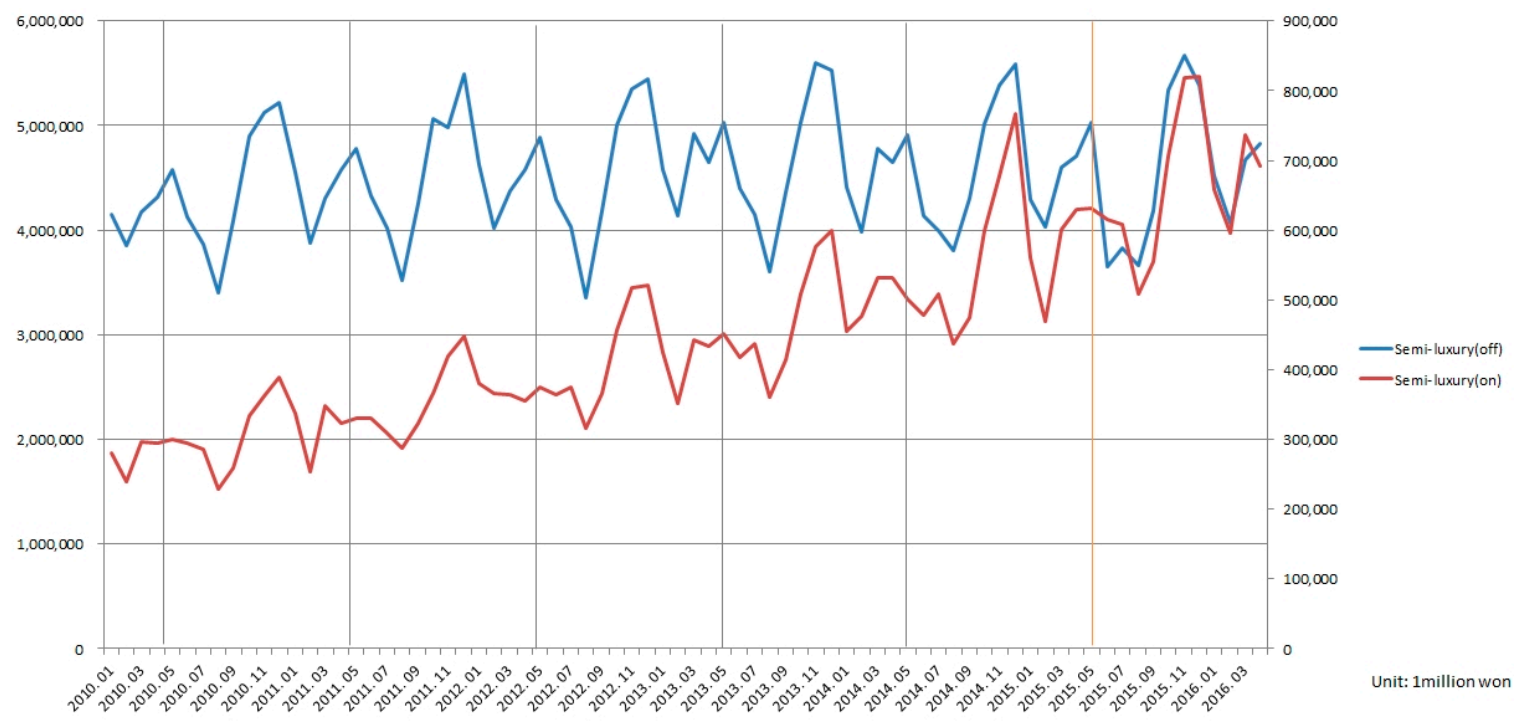

Figure 5. Time series plot for semi-luxury goods.

As indicated in Table 3, the analysis of offline sales of semi-luxury goods from the final model suggests that sales in June and July dropped by about $22.12 \%=\{1-\exp (-0.152-0.073-0.069)\} \times 100$ due to the MERS epidemic that began in May 2015. This result suggests that the outbreak led to a reduction in offline sales for two months. The intervention model for online sales was not significant. Therefore, we analyzed further using the ARIMA model for the complete time series, including the time the epidemic began. This resulted in little difference between the AIC of the intervention model $(-179.36)$ and that of the full ARIMA model $(-178.59)$, thus indicating that the MERS epidemic led to a decrease in offline sales and had no significant effect on online sales. We estimate that the offline sales of semi-luxury goods fell to about $22.12 \%$ in June and July. There can be several reasons for this decrease in sales for two months in a row. First, unlike groceries, the nature of these products does not satisfy 
consumers' basic needs and they are not vital for daily business, like electronic goods. Additionally, while consumers may feel the need to purchase them, they are durable, so consumers can delay their purchase. As Dhar and Wertenbroch and Ha et al. mentioned, people like to buy semi-luxury goods not because they should, but because they want to $[47,79]$. Thus, we can infer that consumers did not feel a strong need to buy semi-luxury goods in the 69 days of the MERS epidemic. Second, fewer foreigners visited the country [19]. According to the Ministry of Culture, Sports and Tourism, more than $80 \%$ of the foreign tourists visit Seoul, mainly because they like to shop there [71,80]. Thus, the lower tourist numbers may explain the fall in offline sales of semi-luxury goods during the epidemic.

Meanwhile, the intervention did not affect online sales, meaning that the MERS epidemic did not transform consumers' online shopping patterns for semi-luxury goods. This is partly because the MERS outbreak did not change the online markets' shopping environment and consumers could buy semi-luxury goods whenever they wanted to, even during the MERS outbreak. However, the time series plot indicates that sales declined less than they did before the period, suggesting that the MERS intervention had a slight effect. In conclusion, these results demonstrate that the delay effect exists in offline markets for semi-luxury goods, thus supporting Hypothesis 1.

Table 3. Offline sales results.

\begin{tabular}{|c|c|c|c|c|c|c|c|}
\hline \multicolumn{4}{|c|}{ Offline } & \multicolumn{4}{|c|}{ Online } \\
\hline & Estimates & $\begin{array}{l}\text { Standard } \\
\text { Error }\end{array}$ & $p$-Value & & Estimates & $\begin{array}{l}\text { Standard } \\
\text { Error }\end{array}$ & $p$-Value \\
\hline$\phi$ & -0.62 & 0.145 & 0.00 & $\theta$ & -0.589 & 0.117 & 0.00 \\
\hline$\theta_{1}$ & 0.88 & 0.159 & 0.00 & $\Phi$ & -0.6 & 0.108 & 0.00 \\
\hline$\theta_{2}$ & 0.335 & 0.193 & 0.09 & $\omega_{0}$ & -0.007 & 0.047 & 0.88 \\
\hline$\theta_{3}$ & 0.546 & 0.112 & 0.00 & & & & \\
\hline$\theta_{4}$ & 0.936 & 0.146 & 0.00 & & & & \\
\hline$\theta_{5}$ & 0.64 & 0.182 & 0.00 & & & & \\
\hline$\theta_{6}$ & 0.574 & 0.187 & 0.00 & & & & \\
\hline$\omega_{0}$ & -0.16 & 0.023 & 0.00 & & & & \\
\hline$\omega_{1}$ & -0.09 & 0.023 & 0.00 & & & & \\
\hline$\delta_{1}$ & 0.614 & 0.021 & 0.1 & & & & \\
\hline AIC & & -249.22 & & AIC & & -179.36 & \\
\hline
\end{tabular}

Note: $\omega_{i}$ : expected effect at the early part, $\delta_{i}$ : persistent effect, $\phi, \Phi:$ AR polynomial, $\theta, \Theta:$ MA polynomial.

\subsection{Grocery Goods}

Figure 6 presents the time series plot for grocery sales and suggests that offline sales of groceries are heteroscedastic and affected by seasonal factors. Additionally, sales dropped for a month in June after the MERS epidemic began in May 2015. Although there was a slight decline in June of the previous year, a bigger decline occurred in June 2015. Therefore, we investigated whether the MERS outbreak was the cause for this decline. We assumed that the intervention commenced in May 2015, the lag was $b=1$, and the effect materialized only in June 2015, and thus applied $P_{t}$. Online transactions for groceries surged in June after the outbreak of MERS. Considering that sales declined in June as compared to May, we observed that the MERS epidemic influenced online sales. Therefore, we conducted an analysis to calculate $P_{t}$.

As indicated in Table 4, there was no significant effect from the intervention in both online and offline markets. Despite a 5.8\% drop in month-to-month sales in the offline market, the volume of the drop itself was not large enough to indicate an intervention effect. By estimating a seasonal ARIMA model of the complete time series, we confirmed that an ARIMA $(1,1,1)(2,0,0) 12$ model with AIC (251.65) is more appropriate than a model with intervention. Our analysis of online markets also produced similar results, that is, the intervention did not have a significant impact on the online sales of groceries, despite the increase in month-to-month sales. 


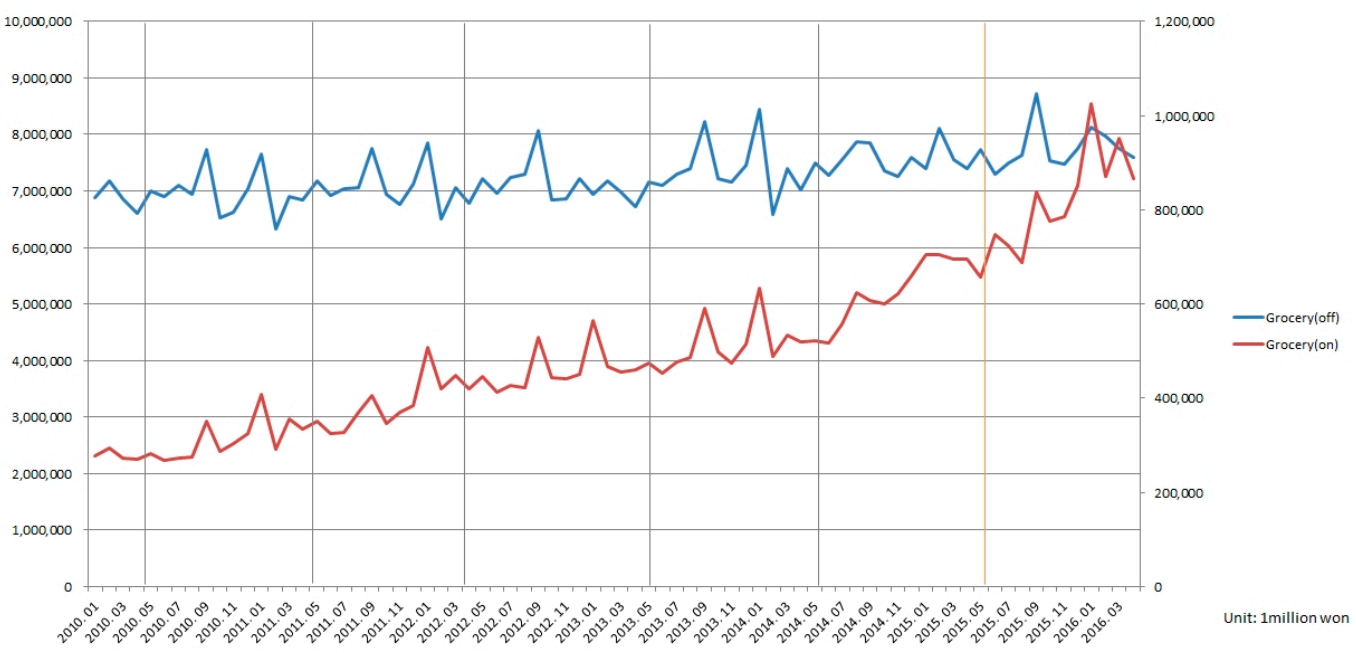

Figure 6. Time series plot for groceries.

Table 4. Groceries results.

\begin{tabular}{cccccccc}
\hline \multicolumn{4}{c}{ Offline } & \multicolumn{5}{c}{ Online } \\
\hline & \multirow{2}{*}{ Estimates } & $\begin{array}{c}\text { Standard } \\
\text { Error }\end{array}$ & $p$-Value & & Estimates & $\begin{array}{c}\text { Standard } \\
\text { Error }\end{array}$ & $p$-Value \\
& & & & & & \\
\hline $\boldsymbol{\phi}$ & -0.319 & 0.12 & 0.00 & $\boldsymbol{\phi}_{\mathbf{1}}$ & -0.977 & 0.118 & 0.00 \\
$\boldsymbol{\theta}$ & -0.868 & 0.049 & 0.00 & $\boldsymbol{\phi}_{\mathbf{2}}$ & -0.714 & 0.147 & 0.00 \\
$\boldsymbol{\Phi}$ & 0.525 & 0.106 & 0.00 & $\boldsymbol{\phi}_{\mathbf{3}}$ & -0.406 & 0.114 & 0.001 \\
$\omega_{\mathbf{0}}$ & -0.044 & 0.044 & 0.32 & $\boldsymbol{\Phi}$ & 0.67 & 0.089 & 0.00 \\
& & & & $\boldsymbol{\omega}_{\mathbf{0}}$ & -0.032 & 0.047 & 0.5 \\
& & & & $\boldsymbol{\delta}_{\mathbf{1}}$ & 0.788 & 0.285 & 0.00 \\
\hline AIC & & -191.89 & & AIC & & -171.01 & \\
\hline
\end{tabular}

Note: $\omega_{i}$ : expected effect at the early part, $\delta_{i}$ : persistent effect, $\phi, \Phi:$ AR polynomial, $\theta, \Theta:$ MA polynomial.

Sales in both online and offline grocery markets did not change considerably due to the MERS intervention. It seems that, by their nature, groceries are a necessity rather than an option for life; hence, an unexpected event like the MERS epidemic cannot dramatically reduce grocery consumption [9]. However, the time series graphs of online and offline sales tell a different story. The offline sales of groceries experienced a greater decline as compared to the previous year, while the online transactions for groceries dropped in June of the previous years, but rose in June 2015. We predict that some people avoided crowded places like big shopping malls or markets for buying groceries and instead moved to online markets. Thus, the degree of change was not big enough to find a measurable effect between the two markets due to the unexpected MERS outbreak.

\section{Discussion}

This study investigated the duration of the effects of the MERS outbreak on sales of online and offline retail markets and determined how the relationships between the two shopping channels were heterogeneously differentiated with respect to the category of retail goods during that period. The findings indicated that the sales of some offline retail goods decreased during the two months after the MERS outbreak. In addition, our analysis results indicated that online and offline markets had a mutual relationship depending on the characteristics of the products sold.

Based on the test results of our three hypotheses, we can summarize the following findings. First, consumers changed their purchasing behavior for electronic goods by moving from the offline to the online retail market in response to the MERS outbreak. Offline sales decreased by $7.9 \%$, while online sales grew by $7.03 \%$. This finding confirms that the expenditure on most offline retail goods decreased by $6.87 \%$ to $18.01 \%$, while e-commerce shopping increased by $5.24 \%$ during that 
time [9]. That is, consumers opted for online shopping due to concerns about the MERS infection. This behavioral change occurred immediately in June in both online and offline markets. These results demonstrated that the MERS outbreak led to a decline in offline sales and an increase in online sales, and indicated the presence of a substitution effect between the online market and the traditional market for electronic goods with the external shock of the MERS epidemic moving customers to the online market (Hypothesis 1). This can be explained through several previous studies $[6,8,34,80]$. Electronic products are characterized by standard sizes; therefore, consumers do not necessarily feel the need to purchase them offline $[1,48,79]$. It also implies that people prefer quality to convenience when purchasing standardized goods like electronics and tickets, which are homogeneous in nature [49,52].

Second, the MERS outbreak caused a reduction in the offline sales of semi-luxury goods, which dropped continuously for two months in June and July by about $22.12 \%$. In contrast, it did not have a significant effect on the sales variation in the online market during that period. That is, the MERS outbreak did not affect consumers' shift from the offline market to the online market. These results resemble the research results of D'Arpizio [34], who reported the total decrease in retail sales for luxury goods during the SARS outbreak. This may indicate that consumers did not feel like purchasing the goods because of their durable nature [34,63]. Thus, infectious diseases only had a significant effect on offline shopping malls because of reduced outdoor activities, while it did not influence consumers to move to online markets for the goods. It may imply that consumers delayed the purchase of semi-luxury goods through offline channels because these goods are not daily necessities, while their behavior remained unchanged in online markets, which thus remained unaffected. This not only indicates that the two markets for semi-luxury goods are independent, but also that the delay effect exists in the offline market (Hypothesis 2).

Third, the intervention did not have a statistically significant impact on the variation of both online and offline sales of groceries. The finding is consistent with the result of Jung et al. [9] where expenditure on grocery goods in the offline markets did not decrease during the MERS outbreak. Considering the nature of the goods, a dramatic decrease in the demand for groceries is highly unlikely because people consume groceries immediately and prefer to inspect their quality in person before buying them. Studies such as Holbrook and Hirschman and Grabner-Krauter and Kaluscha indicated that a shift to online markets is not easy and becomes even slower in the case of groceries as compared to luxury and electronic goods because consumers want to inspect groceries before purchasing them $[81,82]$. Therefore, the outbreak did not affect the variation in their sales.

In summary, we can confirm that a differentiating and heterogeneous relationship between offline and online markets existed with respect to different product categories (Hypothesis 3 ) during the MERS outbreak. Consumers moved to online markets from offline markets for electronic goods during that period, indicating a substitution relationship between the two. In the case of semi-luxury goods, the two markets were independent of each other, implying the presence of a delay effect. Retail sales for grocery goods on both offline and online markets were not affected by the outbreak and proliferation of the MERS. These differentiating and heterogeneous impacts on the markets for different retail goods may have been caused by individual product attributes. Electronic goods are standardized and do not differ in quality in either market; hence, consumers could easily move to online markets during the MERS outbreak. On the other hand, semi-luxury goods are not necessary enough to be bought on time by consumers to sustain their daily lives; hence, they delayed their consumption during that period. Consumers usually have a propensity to physically inspect and purchase grocery goods, which is necessary to sustain their daily lives. This attribute of grocery goods made them hesitate in moving from offline to online markets.

\section{Conclusions}

A few studies have explored the differentiating and heterogeneous relationship between online and offline markets for different retail goods, but not the duration of the outbreak of airborne infectious diseases such as Severe Acute Respiratory Syndrome (SARS), subtype of influenza A 
virus (H1N1), and Middle East Respiratory Syndrome (MERS). This study applied a new methodology, the autoregressive integrated moving average (ARIMA) model with intervention, to identify the duration for which the effects of the MERS outbreak on retail sales in Korea persisted and whether these effects were statistically significant. The related literature has identified the extent to which the outbreak of unexpected pandemics leads to economic loss in tourism and retail sales $[9,17,18,24-26]$. Most studies employed a direct comparison method [18], a linear regression model [9], or ARIMA model [17]. However, these methodologies have limitations as regards to controlling for trends and seasonal impacts, autocorrelation, and determining the exact size of the impact, respectively. In contrast, by resolving the problems in the aforementioned methodologies, this study demonstrates that the impact persisted for two months after the MERS outbreak, and identified a $7.97 \%$ and $22.12 \%$ monthly loss on the sale of electronic and semi-luxury goods in offline markets, respectively. That is, our research findings imply that its impact on sales in the offline retail market persisted for a short period in the case of certain retail goods, but it did not preserve retail purchase behaviors resulting from a defense mechanism permanently.

Furthermore, this study confirms the differentiating relationships between online and offline markets by product type based on behavior theories: substitution in the case of electronic goods, delay in the case of semi-luxury goods, and no relationship in the case of grocery goods. People tend to change their behavior in response to an unexpected situation like the MERS outbreak. Most previous studies identified a decrease in retail sales as well as economic growth at a macro-level or at the level of a particular sector because of the defense mechanism in people, which is based on the fear of getting infected through outdoor activities. In addition to similar results in previous studies, this study confirmed the possibility of shifting from offline to online markets in the digital age, thus attenuating the external shock in total retail sales. In addition, the impact of the external shock caused by the spread of disease on retail sales can be reduced if a virtual shopping experience is provided to potential consumers on the internet, especially for grocery goods.

In conclusion, our research findings imply that stakeholders such as the government and retail agents can provide a strategic approach to deal with the outbreak and proliferation of the MERS. The government needs to consider that citizens have the ability to either purchase retail goods in online markets, or delay their purchase for a while. In this regard, the government should not only recommend citizens to avoid outdoor activities that are not necessary for daily life but also provide information on alternatives such as online purchases. From the perspective of retail agents, this study indicates that there is an alternative strategy to deal with the MERS outbreak. They need to provide potential consumers with diverse purchasing channels such as online channels and omni-channels. Our research results demonstrate that consumers purchased their electronic goods online, rather than offline, to avoid the risk of getting infected through outdoor activities. However, consumers did not curb their offline purchases of grocery goods, which comprise daily necessities, despite the risk. Retailers need to provide the information on using omni-channels, which enable consumers to purchase goods on the online market which could be also accessed through the offline market. This behavior allows them to avoid getting infected. In recent years, many retail firms have started to establish omni-channels to deal with the behavioral changes of consumers in the digital age. It means that firms with appropriate systems can avoid incurring severe losses in retail sales, even if a crisis occurs unexpectedly.

Despite these findings, our study was limited in explaining why retail sales are heterogeneously differentiated for different categories of retail goods and between online and offline markets. Our conclusions were mostly based on contextual interpretations. In this regard, further studies in the near future need to explore why consumers respond differently to the outbreak of airborne infectious diseases in the context of retail expenditures by directly connecting consumers' psychology and behavior to the attributes of retail goods.

Acknowledgments: This research was supported by the National Research Foundation of Korea grant, which is funded by the Government of South Korea (NRF-2015R1A2A2A03007992 and NRF-2010-0028693). 
Author Contributions: E.J. conceived and designed the research, collected and analyzed the data, and wrote the manuscript; H.S. contributed to the research idea, constructed the overall research framework, and provided suggestions on practical implications and conducted manuscript revision.

Conflicts of Interest: The authors declare no conflict of interest. The founding sponsors had no role in the design of the study; collection, analyses, or interpretation of data; writing of the manuscript; and the decision to publish the results.

\section{Appendix A. Decomposition of Retail Sales by Offline and Online Goods}

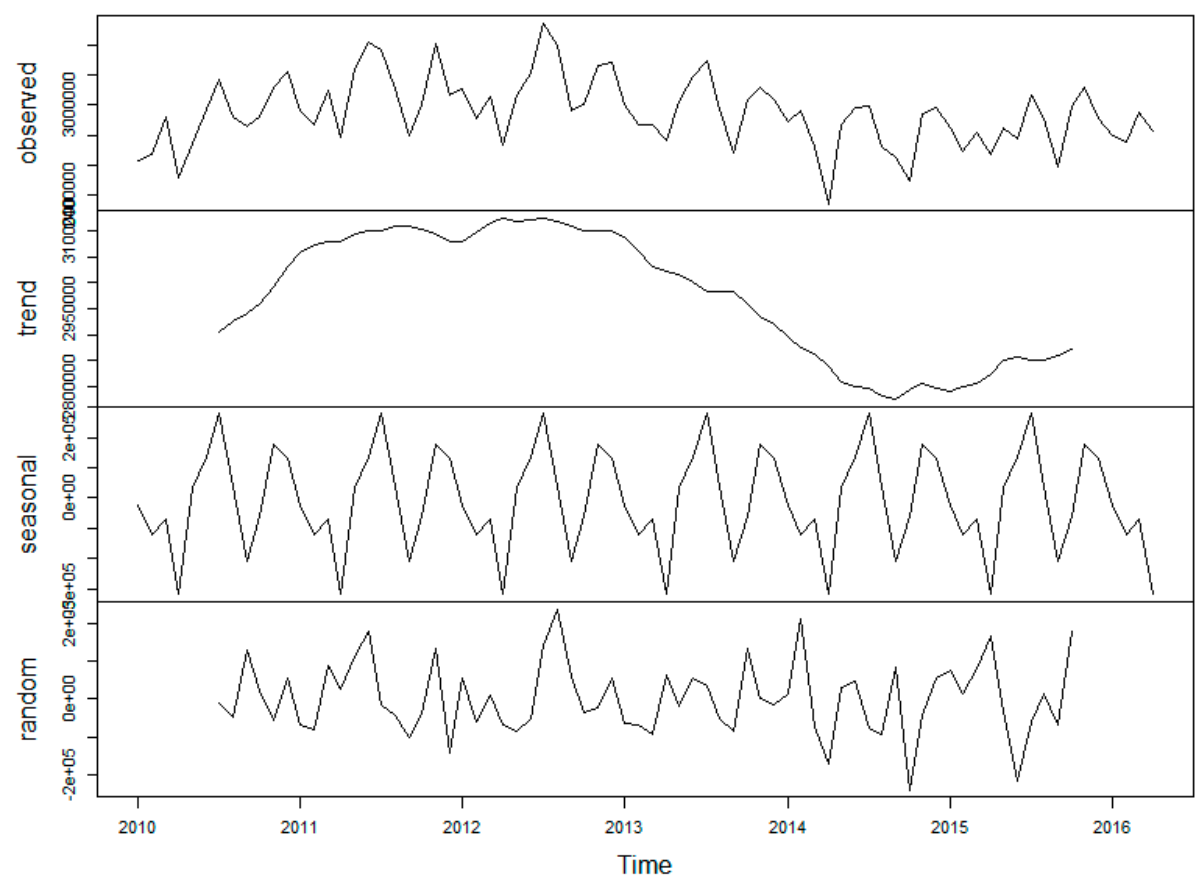

(a)

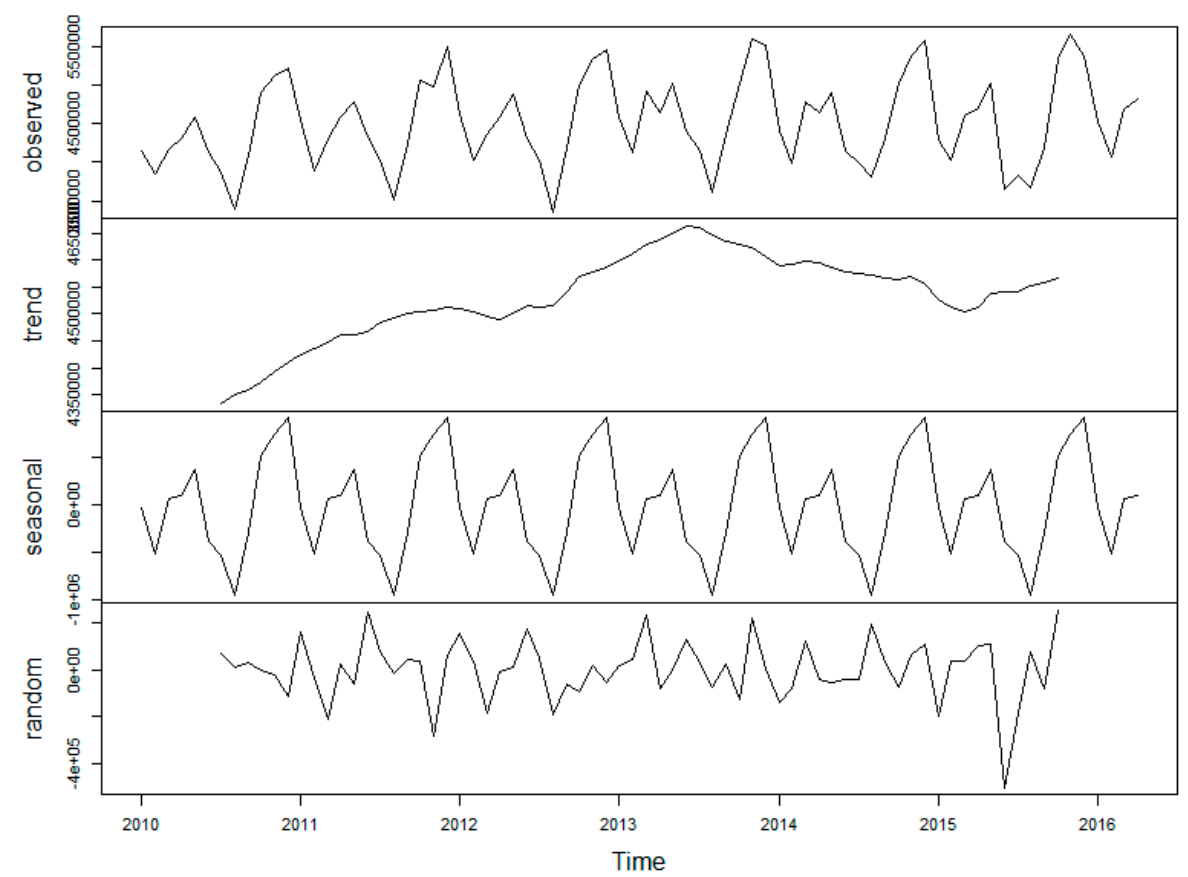

(b)

Figure A1. Cont. 


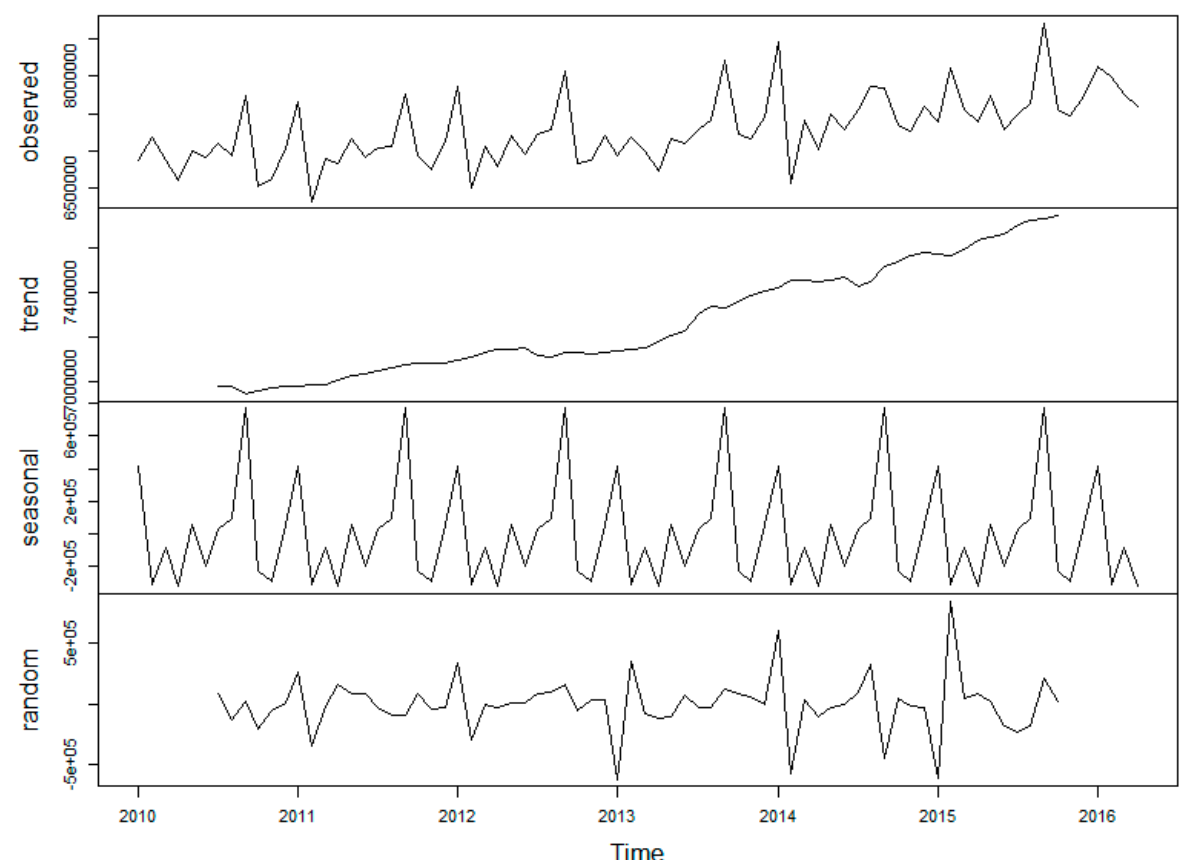

(c)

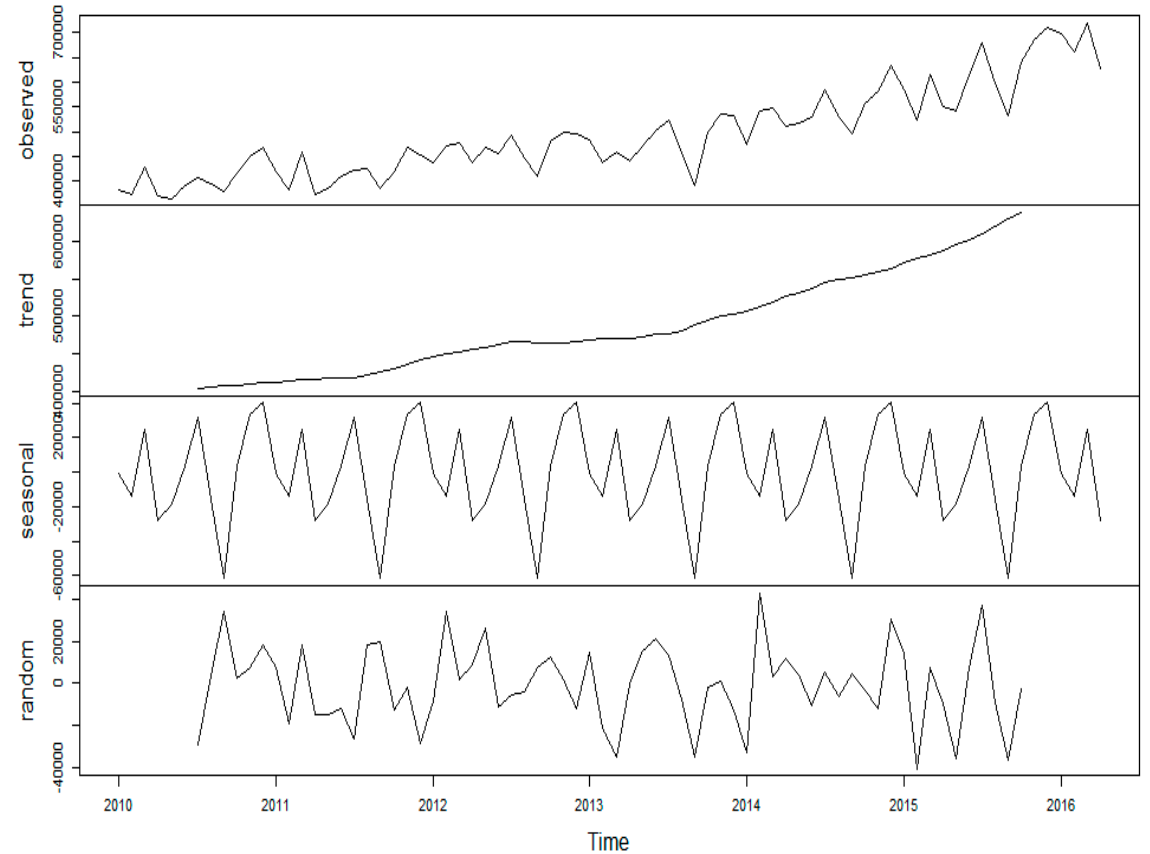

(d)

Figure A1. Cont. 


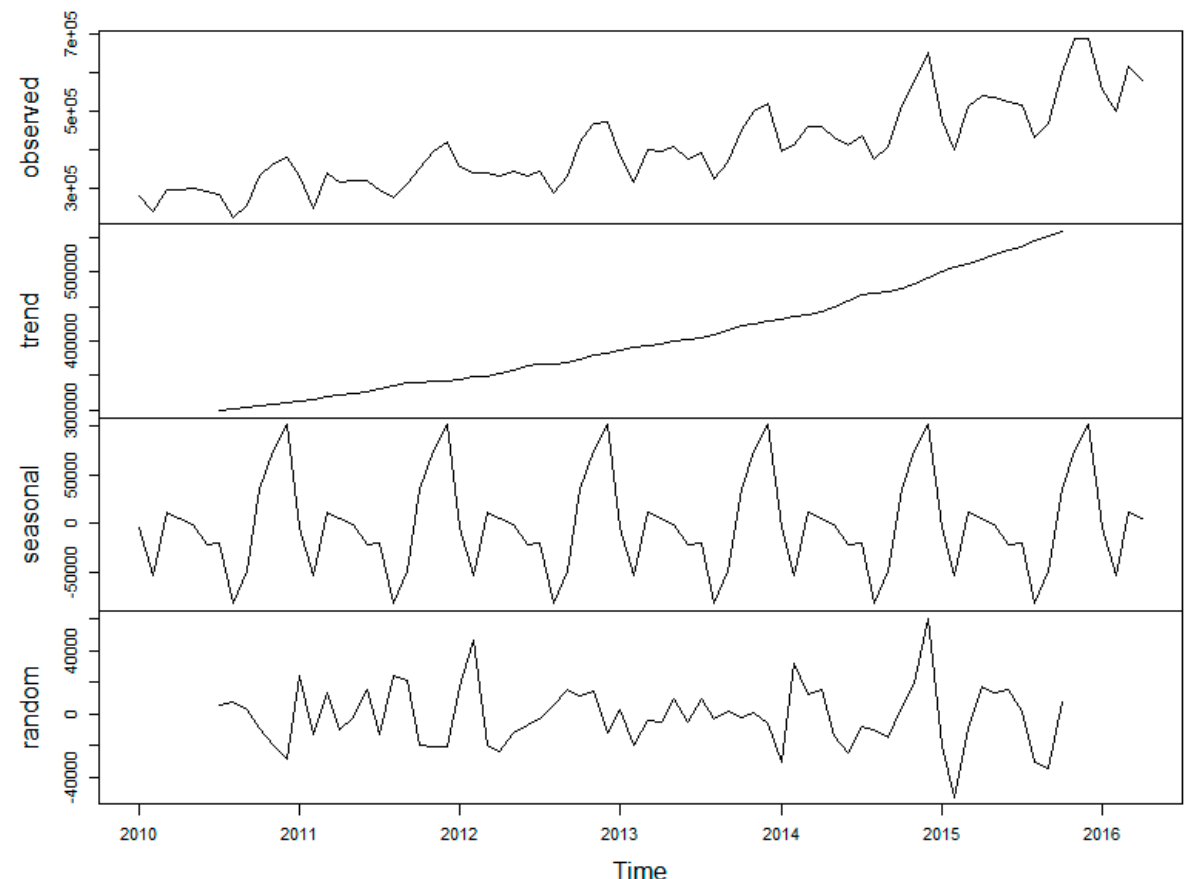

(e)

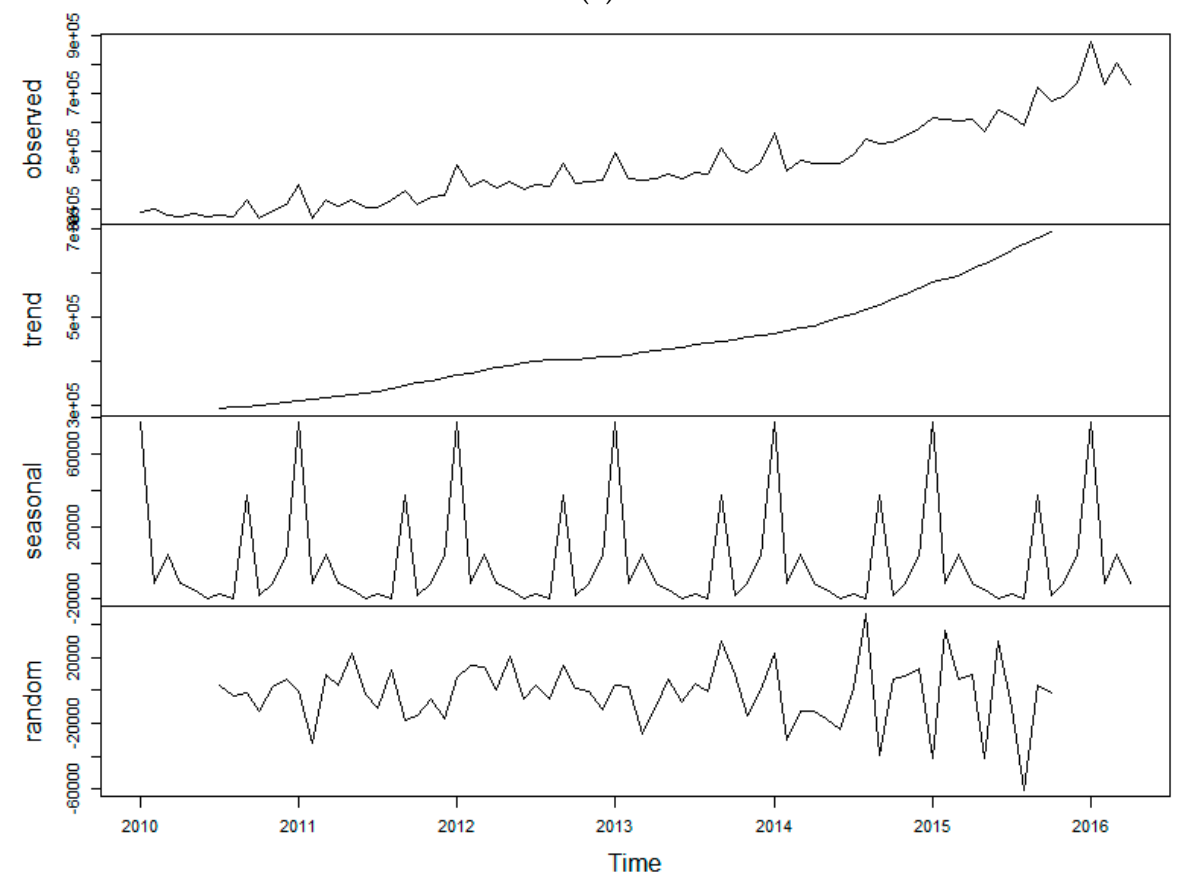

(f)

Figure A1. (a) Offline electronic goods; (b) Offline semi-luxury goods; (c) Offline grocery goods; (d) Online electronic goods; (e) Online luxury goods; (f) Online grocery goods. 


\section{Appendix B. Monthly Comparison of Retail Sales for the Same Months of 2014 and 2015}

Table A1. Monthly Comparison of Retail Sales for the Same Months of 2014 and 2015 (Unit: billion Korean won).

\begin{tabular}{|c|c|c|c|c|c|c|c|c|c|c|c|c|c|c|}
\hline & & & January & February & March & April & May & June & July & August & September & October & November & December \\
\hline \multirow{6}{*}{$\begin{array}{l}\text { Electronic } \\
\text { goods }\end{array}$} & \multirow{3}{*}{ offline } & 2014 & 2888.7 & 2962.6 & 2720.3 & 2346.7 & 2873.6 & 2985.5 & 2998.8 & 2729.0 & 2652.2 & 2493.0 & 2942.1 & 2985.8 \\
\hline & & 2015 & 2846.0 & 2693.2 & 2819.1 & 2670.9 & 2852.9 & 2777.1 & 3071.2 & 2907.4 & 2586.2 & 2991.2 & 3115.7 & 2906.9 \\
\hline & & Change (\%) & -1.48 & -9.09 & 3.63 & 13.81 & -0.72 & -6.98 & 2.41 & 6.54 & -2.49 & 19.98 & 5.90 & -2.64 \\
\hline & \multirow{3}{*}{ online } & 2014 & 473.4 & 541.7 & 547.6 & 509.6 & 516.2 & 530.8 & 583.1 & 527.8 & 494.7 & 556.9 & 580.8 & 634.1 \\
\hline & & 2015 & 584.3 & 523.7 & 615.1 & 549.6 & 541.7 & 614.3 & 679.9 & 596.5 & 533.3 & 640.0 & 686.0 & 709.2 \\
\hline & & Change (\%) & 23.42 & -3.32 & 12.32 & 7.84 & 4.94 & 15.73 & 16.60 & 13.02 & 7.81 & 14.91 & 18.13 & 11.83 \\
\hline \multirow{6}{*}{$\begin{array}{l}\text { Semi-luxury } \\
\text { goods }\end{array}$} & \multirow{3}{*}{ offline } & 2014 & 4412.4 & 3989.6 & 4776.5 & 4646.3 & 4906.4 & 4144.4 & 3997.6 & 3804.9 & 4307.3 & 5013.4 & 5389.3 & 5582.4 \\
\hline & & 2015 & 4295.6 & 4033.8 & 4601.5 & 4710.2 & 5024.9 & 3647.8 & 3824.9 & 3668.1 & 4187.2 & 5342.8 & 5669.4 & 5385.4 \\
\hline & & Change (\%) & -2.65 & 1.11 & -3.66 & 1.38 & 2.42 & -11.98 & -4.32 & -3.60 & -2.79 & 6.57 & 5.20 & -3.53 \\
\hline & \multirow{3}{*}{ online } & 2014 & 396.2 & 415.1 & 463.1 & 463.1 & 434.2 & 411.5 & 438.2 & 377.2 & 407.8 & 515.8 & 577.9 & 654.2 \\
\hline & & 2015 & 477.2 & 401.8 & 513.5 & 540.0 & 538.5 & 525.5 & 518.7 & 432.4 & 470.8 & 601.8 & 690.8 & 690.2 \\
\hline & & Change (\%) & 20.42 & -3.21 & 10.87 & 16.59 & 24.03 & 27.70 & 18.36 & 14.65 & 15.45 & 16.68 & 19.54 & 5.50 \\
\hline \multirow{6}{*}{ Groceries } & \multirow{3}{*}{ offline } & 2014 & 8450.7 & 6575.9 & 7403.9 & 7019.6 & 7492.1 & 7275.8 & 7556.8 & 7866.2 & 7842.2 & 7355.6 & 7260.7 & 7600.2 \\
\hline & & 2015 & 7386.1 & 8104.7 & 7554.8 & 7397.0 & 7740.6 & 7292.5 & 7495.7 & 7637.6 & 8713.6 & 7542.6 & 7473.8 & 7742.2 \\
\hline & & Change (\%) & -12.60 & 23.25 & 2.04 & 5.38 & 3.32 & 0.23 & -0.81 & -2.91 & 11.11 & 2.54 & 2.93 & 1.87 \\
\hline & \multirow{3}{*}{ online } & 2014 & 562.1 & 429.3 & 468.2 & 457.2 & 458.4 & 455.3 & 490.4 & 543.4 & 527.2 & 529.8 & 550.3 & 581.0 \\
\hline & & 2015 & 613.8 & 610.0 & 606.6 & 607.8 & 565.4 & 642.5 & 622.9 & 587.1 & 719.5 & 673.8 & 687.9 & 737.3 \\
\hline & & Change (\%) & 9.20 & 42.09 & 29.56 & 32.94 & 23.34 & 41.10 & 27.01 & 8.03 & 36.47 & 27.18 & 25.00 & 26.90 \\
\hline
\end{tabular}

Note: The highlighted cells indicate that retail sales decreased in 2015, compared to the same month in 2014. 


\section{References}

1. Wang, Q.; Song, P.; Yang, X. Understanding the substitution effect between online and traditional channels: Evidence from product attributes perspective. Electron. Mark. 2013, 23, 227-239. [CrossRef]

2. Kim, J.W. Impact of Electronic Commerce Growth on Traditional Retail Store. Unpublished Master's Thesis, Hanyang University, Seoul, Korea, 2002.

3. Jung, E.A.; Sung, H.G. The effects of homogeneous and heterogeneous Spatial Clustering characteristics on retail sales in Seoul. J. Korea Plan. Assoc. 2016, 51, 63-83. [CrossRef]

4. Weltevreden, J.W.J. Substitution or complementarity? How the internet changes city centre shopping. J. Retail. Consum. Serv. 2007, 14, 192-207. [CrossRef]

5. Kim, T.H.; Lee, H.H. Considerations left behind Middle East respiratory syndrome coronavirus (MERS-CoV) outbreaks in Republic of Korea. J. Menopausal Med. 2015, 21, 63-64. [CrossRef] [PubMed]

6. Kim, W.J. A study on the impact of the epidemic disease on number of books checked out of the public libraries: Based on the Middle East Respiratory Syndrome Coronavirus. J. Korean Soc. Inf. Manag. 2015, 32, 273-287. [CrossRef]

7. Wang, K.Y. How change of public transportation usage reveals fear of the SARS virus in a city. PLoS ONE 2014, 9, e89405. [CrossRef] [PubMed]

8. Deleersnyder, B.B.; Dekimpe, M.G.; Sarvary, M.; Parker, P.M. Weathering tight economic times: The sales evolution of consumer durables over the business cycle. Quant. Mark. Econ. 2004, 2, 347-383. [CrossRef]

9. Jung, H.J.; Park, M.J.; Hong, K.H.; Hyun, E.J. The impact of an epidemic outbreak on consumer expenditures: An empirical assessment for MERS Korea. Sustainability 2016, 8, 454. [CrossRef]

10. KEIT. Available online: http://www.kiet.re.kr/kiet_web/?sub_num=9\&state=view\&idx=51116 (accessed on 12 August 2016).

11. Chien, G.C.; Law, R. The impact of the Severe Acute Respiratory Syndrome on hotels: A case study of Hong Kong. Int. J. Hosp. Manag. 2003, 22, 327-332. [CrossRef]

12. Moon, J.H.; Han, S.L. Analysis of the influence of MERS epidemic on the retailing industry of Seoul City. J. Channel Retail. 2016, 21, 129-152.

13. Bloom, D.E.; Mahal, A.S. Does the AIDS epidemic threaten economic growth? J. Econometr. 1997, 77, $105-124$. [CrossRef]

14. Taylor, J.B. Analysis of Daily Sales Data during the Financial Panic of 2008. Unpublished work, 2009. Available online: https://pdfs.semanticscholar.org/8698/8d998dae1a2b52e44aa6189353e5a28600e9.pdf (accessed on 16 June 2016).

15. Kim, S.Y.; Seong, B.C. Intervention analysis of Korea tourism data. Korean J. Appl. Stat. 2011, 24, 735-743. [CrossRef]

16. Kilcourse, B.; Rowen, S. Finding the Integrated Multichannel Retailer; Retail Systems Research: Miami, FL, USA, 2008.

17. Sung, H. Impacts of the Outbreak and Proliferation of the Middle East Respiratory Syndrome on Rail Transit Ridership in the Seoul Metropolitan City. J. Korea Plan. Assoc. 2016, 51, 163-179. [CrossRef]

18. Kim, C.; Cheon, S.H.; Seong, H.M.; Hwang, J.; Choi, K.; Joh, C.H. Exposure to fear: An analysis of behavioral change under MERS spread in Seoul. In Proceedings of the Transportation Research Board 95th Annual Meeting, Washington, DC, USA, 14 January 2016.

19. Sung, H.; Kwak, M. Mediation Impacts of Physical Urban Form on Rail Transit Ridership by the Infection Fear of the Middle East Respiratory Syndrome: Focused on the Rail Station Area in Seoul, Korea. J. Korean Plann. Assoc. 2016, 51, 165-180. [CrossRef]

20. Zwart, O.; Veldhuijzen, I.K.; Elam, G.; Arja, A.R.; Abraham, T.; Bishop, G.D.; Richardus, J.H.; Brug, J. Avian Influenza Risk Perception, Europe and Asia. Emerg. Infect. Dis. 2007, 13, 290-293. [CrossRef] [PubMed]

21. Sands, P.; Mundaca-Shah, C.; Dzau, V.J. The neglected dimension of global security-A framework for countering infectious-disease crises. N. Engl. J. Med. 2016, 374, 1281-1287. [CrossRef] [PubMed]

22. Chi, J.; Baek, J.L.J.; Werner, R. The macroeconomic effects of a pandemic in Europe-A model-based assessment. Eur. Comm. Econ. Pap. 2006. [CrossRef]

23. Galbraith, J.W.; Tkacz, G. Analyzing economic effects of September 11 and other extreme events using debit and payments system data. Can. Public Policy 2013, 39, 119-134. [CrossRef] 
24. Zhang, G.; Wei, X. The Impact of SARS on China's Tourism Industry and the Recovery Strategy; Social Science Documentation Publishing House: Beijing, China, 2003.

25. Wen, Z.; Huimin, G.; Kavanaugh, R.R. The impacts of SARS on the consumer behaviour of Chinese domestic tourists. Curr. Issues Tour. 2005, 8, 22-38. [CrossRef]

26. Liu, Y.V.; Massare, M.J.; Barnard, D.L.; Kort, T.; Nathan, M.; Wang, L.; Smith, G. Chimeric severe acute respiratory syndrome coronavirus (SARS-CoV) $\mathrm{S}$ glycoprotein and influenza matrix 1 efficiently form virus-like particles (VLPs) that protect mice against challenge with SARS-CoV. Vaccine 2011, 29, 6606-6613. [CrossRef] [PubMed]

27. Chi, J.; Baek, J. Dynamic relationship between air transport demand and economic growth in the United States: A new look. Transp. Policy 2013, 29, 257-260. [CrossRef]

28. Lee, J.W.; McKibbin, W.J. Estimating the global economic costs of SARS. In Learning from SARS: Preparing for the Next Disease Outbreak-Workshop Summary; National Academy of Sciences: Washington, DC, USA, 2004.

29. Siu, A.; Wong, Y.R. Economic impact of SARS: The case of Hong Kong. Asian Econ. Pap. 2004, 3, 62-83. [CrossRef]

30. Fenichel, E.P.; Kuminoff, N.V.; Chowell, G. Skip the trip: Air Travelers' behavioral responses to pandemic influenza. PLoS ONE 2013, 8, e58249. [CrossRef] [PubMed]

31. Jonung, L.; Roeger, W. The macroeconomic effects of a pandemic in Europe-A model-based assessment. SSRN Electron. J. 2006. [CrossRef]

32. Rittichainuwat, B.N.; Chakraborty, G. Perceived travel risks regarding terrorism and disease: The case of Thailand. Tour. Manag. 2009, 30, 410-418. [CrossRef]

33. D'Arpizio, C. World Luxury Markets Monitor: 2015 Spring Update; Bain \& Company: Milan, Italy, 2015.

34. Ryu, G.H. Harm and future works on tourism by MERS outbreak. Korea Tour. Policy 2015, 9, 8-17.

35. Hanna, D.; Huang, Y. The impact of SARS on Asian economies. Asian Econ. Pap. 2004, 3, 102-112. [CrossRef]

36. Durai, P.; Batool, M.; Shah, M.; Choi, S. Middle East respiratory syndrome coronavirus: Transmission, virology and therapeutic targeting to aid in outbreak control. Exp. Mol. Med. 2015, 47, e181. [CrossRef] [PubMed]

37. Balkhair, A.; Maamari, K.A.; Alawi, F.B. The struggle against MERS-CoV (The novel coronavirus). Oman Med. J. 2013, 28, 226-227. [CrossRef] [PubMed]

38. Tambo, E.; Oljira, T.; Oluwasogo, O.A.; Khater, E.M.; Xiao-Non, Z. Averting MERS-Cov emerging threat and epidemics: The importance of community alertness and preparedness policies and programs. J. Prev. Infect. Control 2015, 1, 1-6. [CrossRef]

39. The Seoul City Government. White Paper for Prevention on the Middle East Respiratory Syndrome Coronavirus; Seoul city: Seoul, Korea, 2015.

40. Higgins, E.T. Beyond pleasure and pain. Am. Psychol. 1997, 52, 1280-1300. [CrossRef] [PubMed]

41. Freud, A. The Ego and the Mechanisms of Defense; Hogarth Press: New York, NY, USA, 1936.

42. Werth, L.; Foerster, J. How regulatory focus influence consumer behavior. Eur. J. Soc. Psychol. 2007, 37, 33-51. [CrossRef]

43. Moussaïd, M. Opinion formation and the collective dynamics of risk perception. PLoS ONE 2013, 8, e84592. [CrossRef] [PubMed]

44. Vaillant, G.E. The historical origins of Sigmund Freud's concept of the mechanisms of defense. In Ego Mechanisms of Defense: A Guide for Clinicians and Researchers; American Psychiatric Association Press: Washington, DC, USA, 1992; pp. 3-28.

45. Cramer, P. Protecting the Self: Defense Mechanisms in Action; Guilford Press: New York, NY, USA, 2006.

46. Choi, J.W.; Jeon, Y.S.; Na, J.Y. A Study on the Expanded Consumer Roles in IT Environment. Consum. Policy Educ. Rev. 2015, 11, 55-78. [CrossRef]

47. Dhar, R.; Wertenbroch, K. Consumer choice between hedonic and utilitarian goods. J. Mark. Res. 2000, 37, 60-71. [CrossRef]

48. Levin, A.M.; Levin, I.R.; Heath, C.E. Product category dependent consumer preferences for online and offline shopping features and their influence on multi-channel retail alliances. J. Electron. Comm. Res. 2003, 4, 85-93.

49. Chellappa, R.K. Consumers' Trust in Electronic Commerce Transactions: The Role of Perceived Privacy and Perceived Security. Available online: http://www.bus.emory.edu/ram/papers/sec-priv.pdf (accessed on 17 November 2016). 
50. Singh, N.; Yadav, M.; Sahu, O. Consumer acceptance of apparel e-commerce-Ethiopia. Intell. Econ. 2016, 10, 55-62. [CrossRef]

51. Juaneda-Ayensa, E.; Mosquera, A.; Murillo, Y.S. Omnichannel Customer Behavior: Key Drivers of Technology Acceptance and Use and Their Effects on Purchase Intention. Front. Psychol. 2016. [CrossRef] [PubMed]

52. Escobar-Rodríguez, T.; Carvajal-Trujillo, E. Online purchasing tickets for low cost carriers: An application of the unified theory of acceptance and use of technology (UTAUT) model. Tour. Manag. 2014, 43, 70-88. [CrossRef]

53. Levin, A.M.; Levin, I.P.; Weller, J.A. A multi-attribute analysis of preferences for online and offline shopping: Differences across products, consumers, and shopping stages. J. Electron. Comm. Res. 2005, 6, 281.

54. Girard, T.; Silverblatt, R.; Korgaonkar, P. Influence of product class on preference for shopping on the internet. J. Comput. Med. Commun. 2002, 8. [CrossRef]

55. Darby, M.R.; Karni, E. Free competition and the optimal amount of fraud. J. Law Econ. 1973, 16, 67-88. [CrossRef]

56. Rosa, J.A.; Malter, A.J. E-(embodied) knowledge and e-commerce: How physiological factors affect online sales of experiential products. J. Consum. Psychol. 2003, 13, 63-73. [CrossRef]

57. Klein, L.R. Evaluating the potential of interactive media through a new lens: Search versus experience goods. J. Bus. Res. 1998, 41, 195-203. [CrossRef]

58. Weathers, D.; Sharma, S.; Wood, S.L. Effects of online communication practices on consumer perceptions of performance uncertainty for search and experience goods. J. Retail. 2007, 83, 393-401. [CrossRef]

59. Bloch, P.H.; Richins, M.L. A theoretical model for the study of product importance perceptions. J. Mark. 1983, 47, 69-81. [CrossRef]

60. Nelson, P. Information and consumer behavior. J. Political Econ. 1970, 78, 311-329. [CrossRef]

61. Nelson, P. Advertising as information. J. Political Econ. 1974, 82, 729-754. [CrossRef]

62. Brucks, M.; Zeithaml, V.A.; Naylor, G. Price and brand name as indicators of quality dimensions for consumer durables. J. Acad. Mark. Sci. 2000, 28, 359-374. [CrossRef]

63. Hsieh, Y.C.; Chiu, H.C.; Chiang, M.Y. Maintaining a committed online customer: A study across search-experience-credence products. J. Retail. 2005, 81, 75-82. [CrossRef]

64. Zeithaml, V.A.; Bitner, M.J.; Gremier, D.D. Service Marketing: Integrating Customer Focus Across The Firm-4/E, 3rd ed.; McGraw-Hill: Boston, MA, USA, 2006.

65. Zaichkowsky, J.L. Measuring the involvement construct. J. Consum. Res. 1985, 12, 341-352. [CrossRef]

66. Kim, Y.K. Exploratory Study on Online/Offline Conflict Based on Product Attributes: Transaction Cost Theory. Personal communication. Unpublished Master's Thesis, Yonsei University, Seoul, Korea, 2000.

67. Suh, J.C.; Youjae, Y. When brand attitudes affect the customer satisfaction-loyalty relation: The moderating role of product involvement. J. Consum. Psychol. 2006, 16, 145-155. [CrossRef]

68. Asch, D. Competing in the new economy. Eur. Bus. J. 2001, 13, 119.

69. Celsi, R.L.; Olson, J.C. The role of involvement in attention and comprehension processes. J. Consum. Res. 1988, 15, 210-224. [CrossRef]

70. Choi, S.Y.; Choi, B.; Lee, H. Categorizing commercial products for customer oriented online retailing. Comput. Ind. Eng. 2006, 51, 90-101. [CrossRef]

71. KOSIS (Korean Statistical Information Service). Available online: http://kosis.kr/ (accessed on 12 August 2016).

72. Huang, P.; Lurie, N.H.; Mitra, S. Searching for experience on the web: An empirical examination of consumer behavior for search and experience goods. J. Mark. 2009, 73, 55-69. [CrossRef]

73. Jarrett, J.E.; Kyper, E. ARIMA modeling with intervention to forecast and analyze Chinese stock prices. Int. J. Eng. Bus. Manag. 2011, 3, 53-58. [CrossRef]

74. Son, C.H.; Baek, J.I.; Ban, Y.U.; Ha, S.R. The Effects of Mitigation Measures on Flood Damage Prevention in Korea. Sustainability 2015, 7, 16866-16884. [CrossRef]

75. Chung, R.C.; Ip, W.H.; Chan, S.L. An ARIMA-intervention analysis model for the financial crisis in China's manufacturing industry. Int. J. Eng. Bus. Manag. 2009, 1, 15-18. [CrossRef]

76. Park, J.H.; Kim, H.J.; Lee, W.H. A Quantitative Analysis on Institutional Intervention Effect into Urban Transition. Adv. Sci. Technol. Lett. 2016, 140, 79-82.

77. Unnikrishnan, J.; Suresh, K.K. Modelling the Impact of Government Policies on Import on Domestic Price of Indian Gold Using ARIMA Intervention Method. Int. J. Math. Math. Sci. 2016, 2016, 6382926. [CrossRef] 
78. Cheema, A.; Papatla, P. Relative importance of online versus offline information for Internet purchases: Product category and Internet experience effects. J. Bus. Res. 2010, 63, 979-985. [CrossRef]

79. Ha, Y.W.; Ahn, S.; Lee, Y. Consumer choice among alternatives with hedonic and utilitarian attributes: The impact of choice range and mode. J. Consum. Stud. 2002, 13, 139-157.

80. Ministry of Culture, Sports and Tourism. Available online: http://www.mcst.go.kr/web/s_data/research/ researchList.jsp (accessed on 16 June 2016).

81. Holbrook, M.B.; Hirschman, E.C. The experiential aspects of consumption: Consumer fantasies, feelings, and fun. J. Consum. Res. 1982, 9, 132-140. [CrossRef]

82. Grabner-Kräuter, S.; Kaluscha, E.A. Empirical research in on-line trust: A review and critical assessment. Int. J. Hum. Comput. Stud. 2003, 58, 783-812. [CrossRef]

(C) 2017 by the authors. Licensee MDPI, Basel, Switzerland. This article is an open access article distributed under the terms and conditions of the Creative Commons Attribution (CC BY) license (http:/ / creativecommons.org/licenses/by/4.0/). 